経営史学

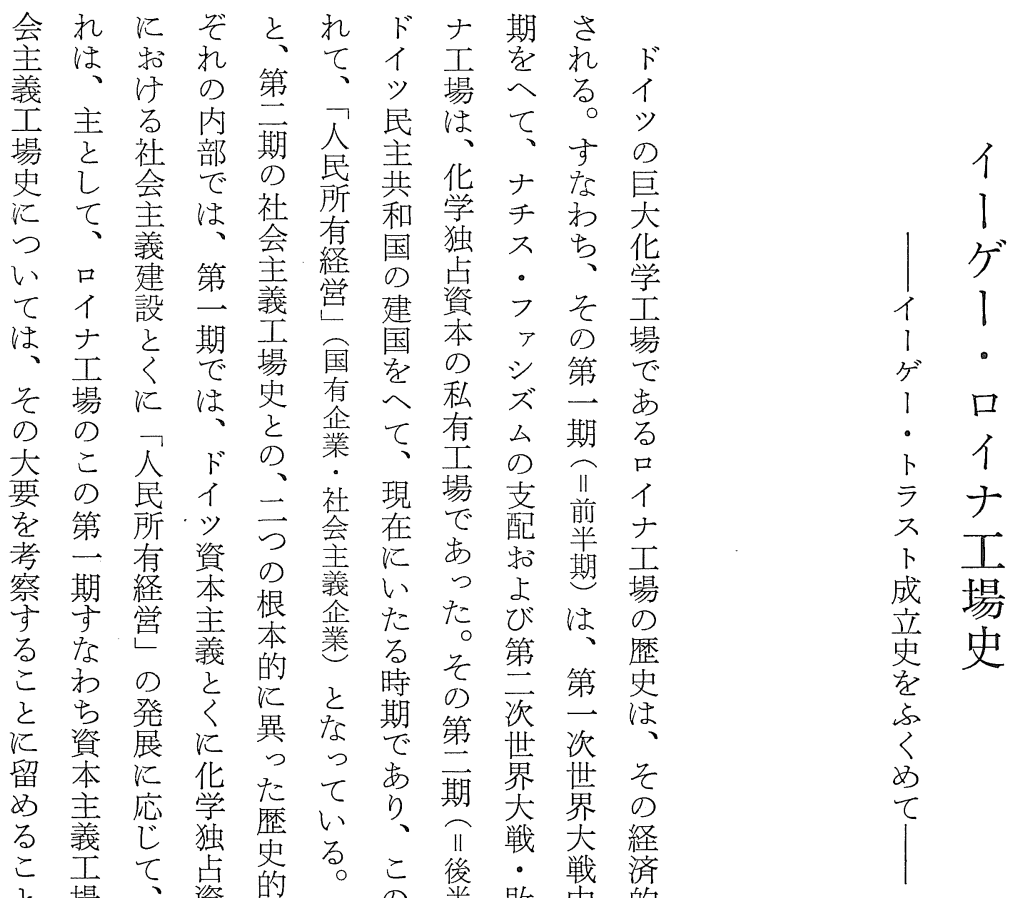
々場、資時加の苚敗中的 々 史々 本期少時期戦少内

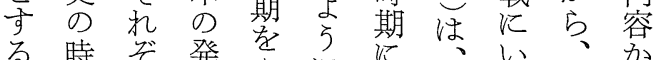

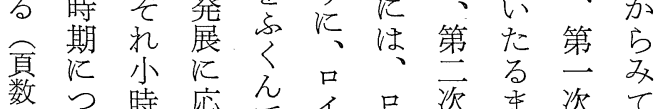

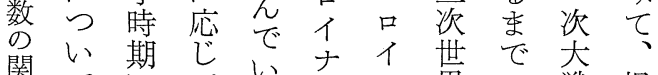
関て期じていざイ 世界の゙戦根 上考 区、合場工 大 時後本 察分交史場戦期 兵的 別しさたた标は資に の、机、拉市本異

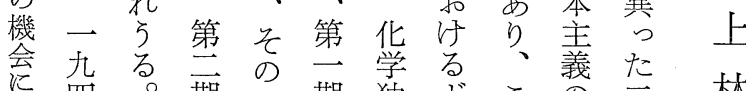
考西 こ 期 察年こ吾この資資 ツ 時時の 貞 た後ばド時本本の期的時 治 々後はド期主美方敗に相期治

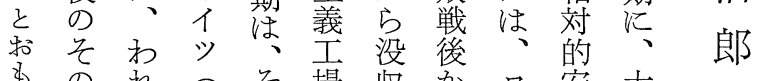

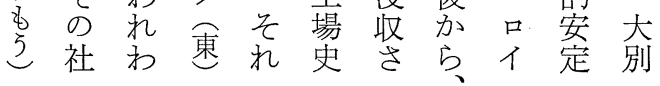


第 2 巻第 2 号

立成品た

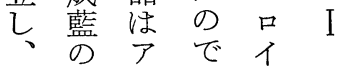

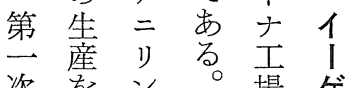

次孝光場 ゲ

戦哈染

中た蚶㻟料

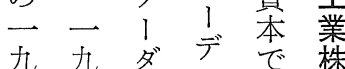

二—ル、ソ年式

六二硫令る 会

年年酸 ア イ 社

に少塩りグ合

イ、籜ン、同

ナ 东

ス! 素ソト

ル ボ酸 ダ ラ 亖

ブシ 硝氕年年

ル法酸芯惊に

ク法市㝕一

により官九不

アる 、总五化

モン八㔬年

毛 $=0$ 吉注た

厂 年吕り分

場高場㤐总ぎ

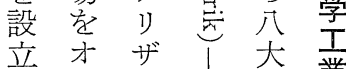

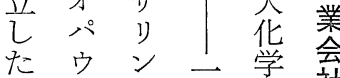

学染八資

こ ヴの 五の

れ、生年集

分上産比中

ス ス、設に

口 $一$ 立よ

1 1 八 妾

土フ九机圭

場 年主成

で設 合製
イなるよ業有

ナっ○り株資口

工場さ监式本イ

のそ場卡前会支 ナ

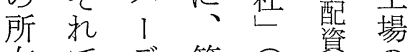

有でデ第 占本 成

たこ社次 天省 の 立

るこ㤎世占成立

イ

1 簡 1 戦 工 発

ゲ単ゲ 中場 展 变

染治! 注々史华

料イト 只て み⿱ み

I1 ラ ハ 知な る

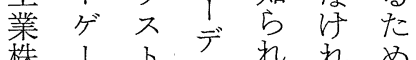

株、式・成ン でれ れ

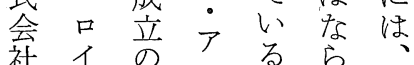

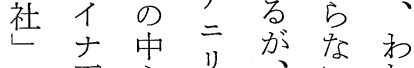

の工心去的

成場会ン そ尤

立史社: の第れ

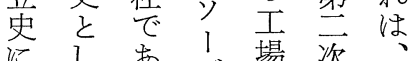

に元市名場次

て特た 業成戦 ず

わ尔式立杰で

又、汗、式、のの

てで口会イロ前

物㐫不社1个史

かるナゲナ物

放口工去 1 工

ば乞場芘・場 び

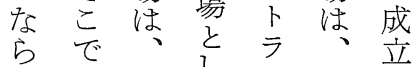

な、当元不立

心わ然湕卜つ発

れ

わイ設成史

れI立立妾

は、゙れた た ぶ

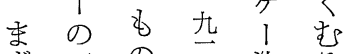

ず場で吾染 料

口と年 年 所 
経 営史学

数過染他に電産硝|の産年チ産新さあ 後数のく、䎡分た立、数りた場、。

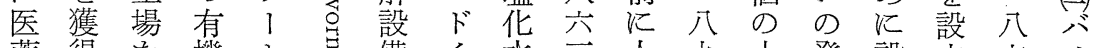

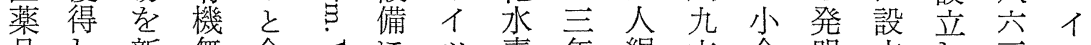
品し 新無 合 に

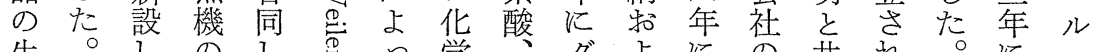
生産 (式) た

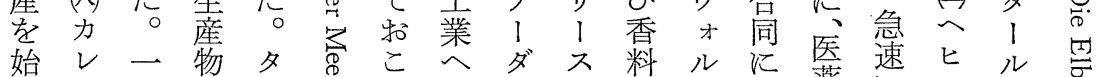

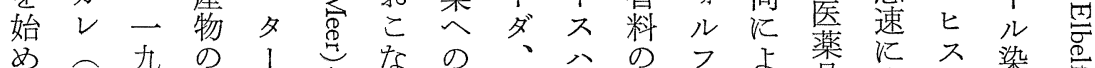
あ

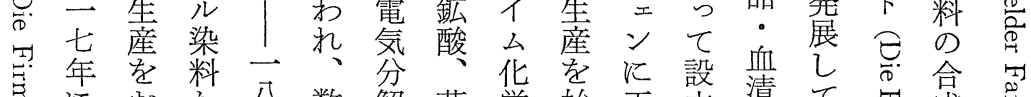

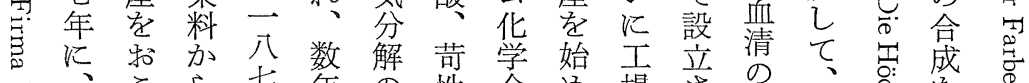
メ、 こ

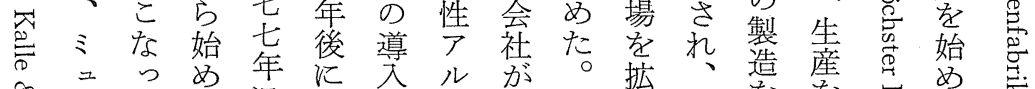

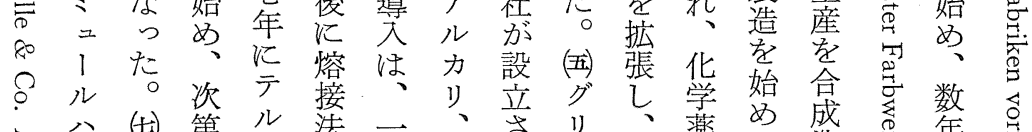

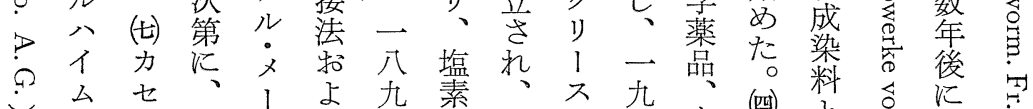
广 染 う 硝 ル び 四素 、

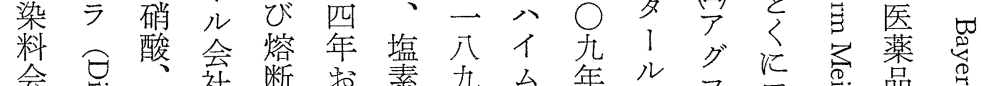

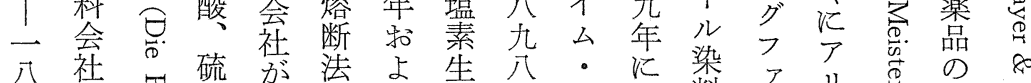

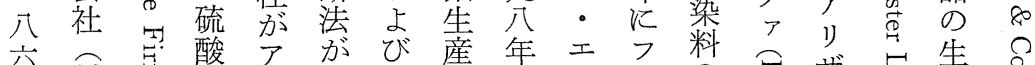

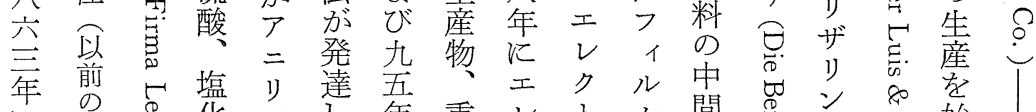
にの

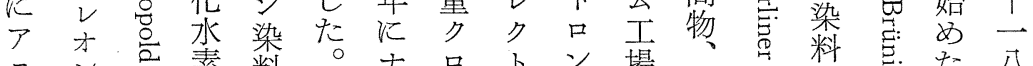

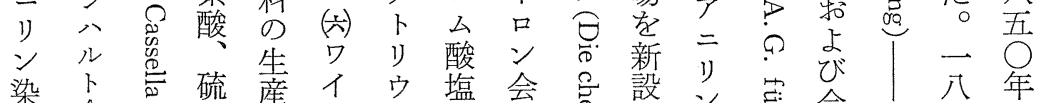
料会

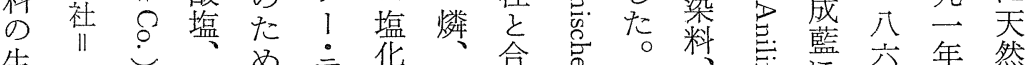

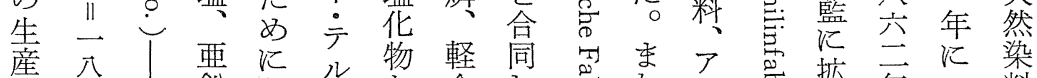
産八 1 亜鉛設

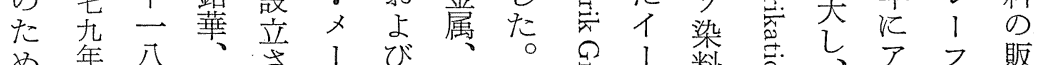

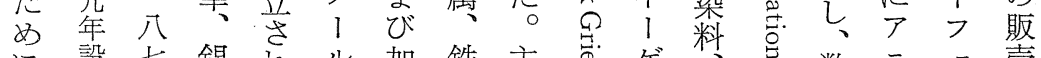
に設 立錫れ れ 加鉄主古 ゙゙料五数二工売

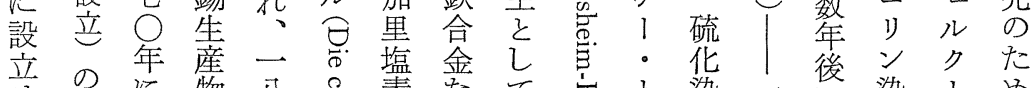

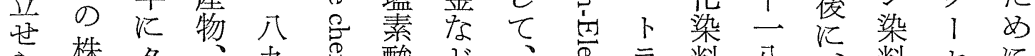

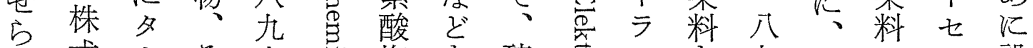

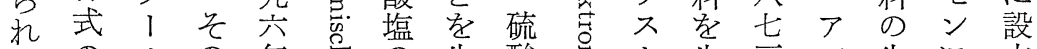

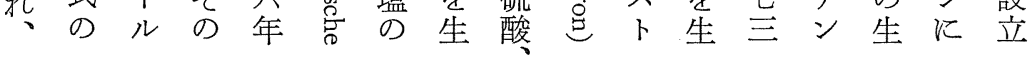


第 2 巻第 2 号

い九る占占に

て○段資産右 II

手

个代表 $(\rightarrow$ 移 成 命

ギににこ行立がゲ

リかよの・発遂 1

ス汀云転展行染

走七て $\bigcirc$ 化しさ料

追急名世乙つ柱

ぬ速明紀た。前资株

以発少後こ查式

て展なにのた主会

以乙上特 時時義 社

る、5 期期㤎

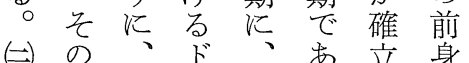

ま輸一个ドる 立身

た出八ツイ的会

当り 六化 9 学 の

時 以年工化てし 設

、て代業学ドて 立

一及加の王个生さ

八れら発業ツ産れ少

九ば、発展㭠資持た発

五、展尔、本よ貣

\begin{tabular}{|c|c|c|c|}
\hline \multicolumn{2}{|c|}{$\begin{array}{l}\text { 第 } 1 \text { 表 輸出入額 } \\
\text { (1) 化学工業輸入額 }\end{array}$} & \multicolumn{2}{|c|}{ (単位 1,000 マルク) } \\
\hline & & ドイッ & イギリス \\
\hline \multirow{3}{*}{ 化学工業原料 } & 1895 & 168,877 & 161,820 \\
\hline & 1905 & 290,559 & 176,041 \\
\hline & 增加額 & 121,682 & 14,211 \\
\hline \multirow[t]{3}{*}{ 化学工業製品 } & 1895 & 110,937 & 143,160 \\
\hline & 1905 & 140,291 & 182,129 \\
\hline & 增加額 & 29,354 & 38,969 \\
\hline
\end{tabular}

期

(ম) 化学工業輸出額 (単位 1,000 マルク)

お

\begin{tabular}{c|c|r|r}
\hline 化学工業原料 & 1895 & 37,264 & 30,303 \\
& 1905 & 66,511 & 40,131 \\
& 増加額 & 29,247 & 9,828 \\
\hline 化学工業製品 & 1895 & 301,883 & 271,869 \\
& 1905 & 475,830 & 309,108 \\
& 增加額 & 173,947 & 37,239 \\
\hline
\end{tabular}

資料 H. Grossmann, Die Bedeutung der chemischen Technik für das deutsche Wirtschaftsleben, 1907.

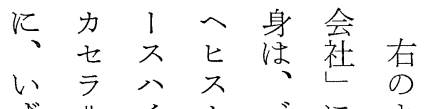
ず ॥イトバによ れ 一 ム $\mid 1$ I 合 5 छ八 $\|$ 古七公公六 过年宍六

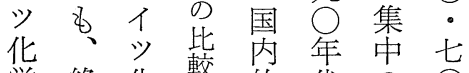

学絶化較的代の○

工対学を江発年

業額工文正ら展代

のに業る国一に情

経扣学々、外九杂、

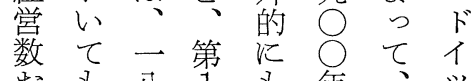

特名八 1 名年、

よ表発代次に

び発○第特

従展年ごしか江い

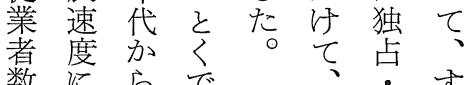

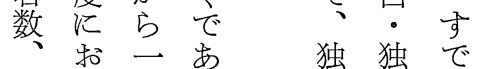

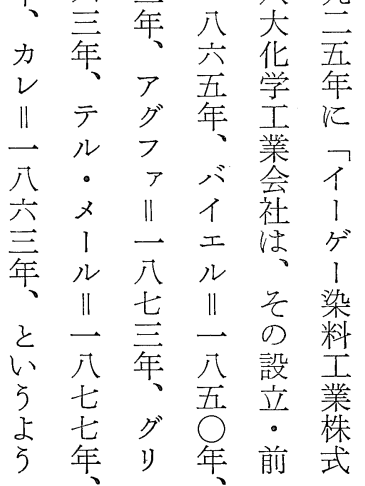


経 営史学

第 2 表 1895 年のドイツ化学工業の経営数执よび従業者数

\begin{tabular}{|c|c|c|c|c|}
\hline & 主 経 営 & 副 経 営 & 計 & 従業者数 \\
\hline 化学工業（合計） & 10,385 & 1,156 & 11,541 & 115,231 \\
\hline 重 化 学 薬 品 & 458 & 20 & 478 & 26,951 \\
\hline その他の化学薬品 & 1,453 & 129 & 1,582 & 12,519 \\
\hline 医 薬 品 & 5,344 & 24 & 5,378 & 15,519 \\
\hline 染 料 原 & 592 & 49 & 641 & 10,386 \\
\hline 鉛 筆 & 53 & 4 & 57 & 276 \\
\hline 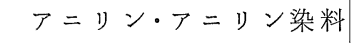 & 25 & - & 25 & 7,266 \\
\hline その他のコールタール誘導物 & 48 & 7 & 55 & 4,194 \\
\hline 爆 発 物 & 212 & 17 & 229 & 16,516 \\
\hline 燐 & 113 & 9 & 122 & 4,815 \\
\hline そ の 他 の 発 火 物 & 95 & 19 & 114 & 1,078 \\
\hline 下剤扣よび消毒郕 & 387 & 38 & 425 & 3,182 \\
\hline 人 造 肥 料 & 385 & 176 & 571 & 8,014 \\
\hline 皮 & 973 & 567 & 1,540 & 1,522 \\
\hline 以下の合計 & 6,192 & 1,933 & 8,124 & 57,909 \\
\hline 木崖扣よびタール & 402 & 257 & 659 & 1,326 \\
\hline ガ ス & 790 & 4 & 794 & 19,512 \\
\hline 樹脂捛よびピッチ & 97 & 27 & 124 & 318 \\
\hline 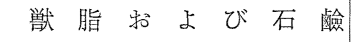 & 1,895 & 160 & 2,055 & 11,204 \\
\hline ステアリン扰よび蠟 & 333 & 78 & 411 & 2,449 \\
\hline 製 油業 & 1,375 & 1,234 & 2,609 & 7,921 \\
\hline コールタール乾溜 & 92 & 17 & 109 & 2,942 \\
\hline 魚油 & 122 & 12 & 134 & 813 \\
\hline 芳香 油 & 206 & 34 & 240 & 2,462 \\
\hline ワニス物よびパテ & 879 & 110 & 989 & 8,962 \\
\hline
\end{tabular}

（注） 1895年 6 月 14 日の「工業調查」.

は吾の者孚規のる門よ強染薬る○以化に气

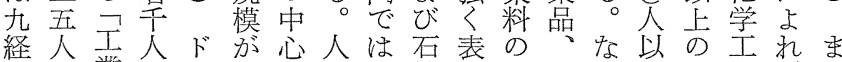
営 、業以イ小部造、襝わ四そ拈上七業ばた

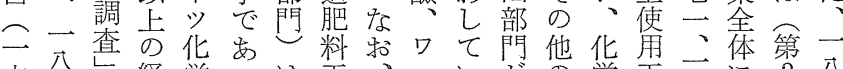
六八九゙経学口は正、

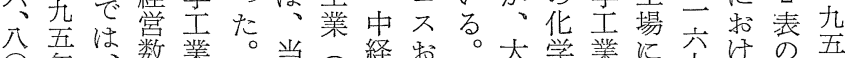
年、数業。当経扣。大学業江六けの五 五の三注に時後営よ医経薬の打泉補年 人経一特年年び薬営品中心ほ従足の 業営分て はの支パ品令爆で働労業的工 一調 西分、1的の獣傾発重い働者説業 八査台三労だゲで恶脂向物化て者半明調 九で八年働、学部扰を学心五数、查

嫢 だで を 当て る れ で华ド少 あ学 个第 り 業 ツ 2 、柴化表 労発学の 働展のご 者 の経と ○営替 口模 あ 人学り 以夕 2 , 上! 斿さ 大のこ注 場営第労 加 規 3 働 支模 表 者 配はに数 的最よに 地もれよ 位大ばる をで、規 乙あア模 めりル別 て、カ いつリ経 るい和営 有唯 有び機酸 染酸八 料業九 爆 年 発华学 燐基文 严第

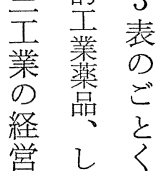




\begin{tabular}{|c|c|c|c|c|c|c|c|c|c|c|}
\hline \multirow{3}{*}{$\begin{array}{l}\text { D } \\
\text { ご } \\
\dot{c} \\
\langle\end{array}$} & \multirow{3}{*}{$\begin{array}{c}\text { 部 } \\
\text { 門 } \\
\text { で } \\
\text { あ } \\
\text { り }\end{array}$} & \multirow{2}{*}{$\begin{array}{l}\text { W } \\
\text { 部 } \\
\text { 門 }\end{array}$} & \multirow{2}{*}{$\begin{array}{l}\text { 牱 } \\
\text { 尔 } \\
\text { る }\end{array}$} & \multirow{2}{*}{$\begin{array}{l}\text { 岁 } \\
\text { 表 } \\
\text { わ }\end{array}$} & $\begin{array}{l}\text { 経 } \\
\text { 営 }\end{array}$ & 1897年の & 労働者偻 & \multicolumn{2}{|c|}{ 文別の経営数（\% } & \\
\hline & & & & & $\begin{array}{l}\text { 数 } \\
\text { は }\end{array}$ & & $\begin{array}{l}100 \text { 人 } \\
\text { 以 }\end{array}$ & $50-100$ & $10-50$ & 10 人以下 \\
\hline & & & & $\tau$ & 約 & 化学工業（全体） & 45.7 & 14.4 & 26.5 & 13.4 \\
\hline & 染 & $=$ & 化 & 万 & & アルカリ执よび酸 & 78.6 & 7.4 & 12.0 & 2.0 \\
\hline & 料 & リ & 学 & & 四 & 写真薬品 ·化学薬品 & 36.9 & 20.2 & 31.8 & 11.1 \\
\hline II & 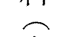 & ン & \lrcorner & 機 & 倍 & 有 機 染 料 & 58.1 & 13.4 & 20.8 & 7.7 \\
\hline 紀 & & 染 & 業 & 械 & , & 発 & 49.9 & 15.8 & 27.4 & 6.9 \\
\hline & $\mu$ & 料 & の & 進 & 労 & 寸 & 44. 1 & 22.3 & 25.7 & 7.9 \\
\hline & 染 & & & 步 & 働 & 肥 & 27.3 & 30.6 & 35.8 & 6.3 \\
\hline & & & & の & 者 & 木炭招よび石炭乾溜 & 20.6 & 15.8 & 40.6 & 23.6 \\
\hline
\end{tabular}

九二関学 九 学数 (注) 1897年の「工業調査」.

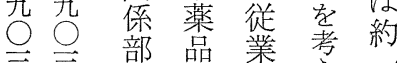

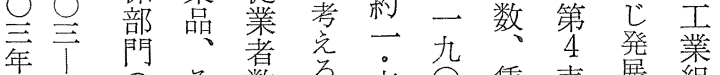

II 六

八年

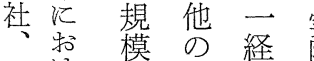

一㲿性化営

九 る

华

四学

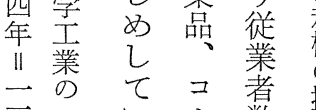

社株

社式

九社

五の

年

II 設

元 $\frac{\text { 立 }}{\text { 数 }}$

社

一特

艺占

六資

年本

II 額

三

社学

でれ

あば

り

そぎ
ルめ

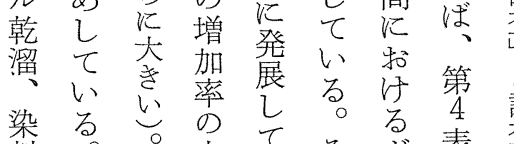

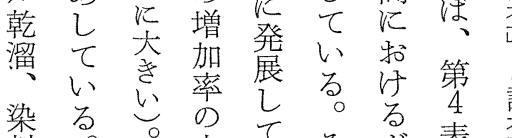

料。原こ方

料れ京杂

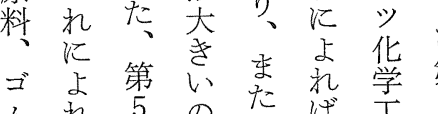

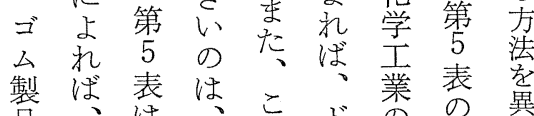

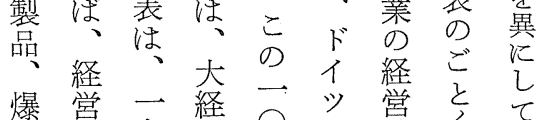

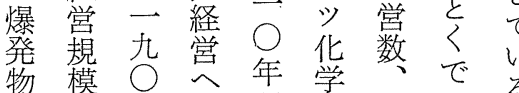

物五の間尒労

の大年傾に業働る

諸き淌、注者
夕学
業経い以

合営て、上七增ン 先 一模一物人過アの

の 九い、程二工

統 拡世紀公学り業

末わ杂㷊り 查

加年、1

たらわ和一ダ三

が三机四八工五

○梳六場経

ぎ紀五吾営

ぎ紀主 吾年後

、衫之注方

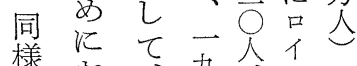

特、九人、

けド○二工あ

る人吾公場る

ツ II 七学

ドの六年建先

イ 兵年設の

ツ、九兄代

さ化業 七忩会的

ら学調金全社な

に㱏查で二に二

ドのつ岕分括例

イ 発䟴る公活と

の沶梳

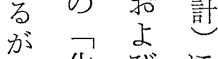

五学て

II 偅者

同学そ 基 三数 


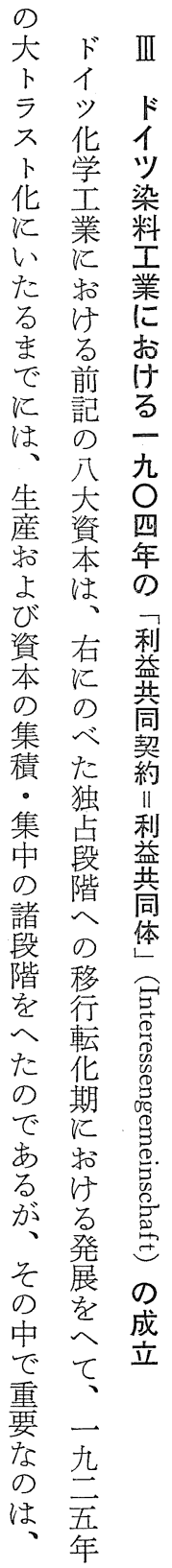

第 4 表 1895-1905年のドイッ化学工業

\begin{tabular}{|c|c|c|c|c|}
\hline & 経 & 営 数 & 労 働 者 数 & $\begin{array}{l}\text { 賈金・給 料 } \\
(100 \text { 万マルグ) }\end{array}$ \\
\hline 1895 & & 5,947 & 114,581 & 97.60 \\
\hline 1896 & & 6,144 & 124,219 & 107.10 \\
\hline 1897 & & 6,316 & 129,827 & 113.37 \\
\hline 1898 & & 6,589 & 135,350 & 121.37 \\
\hline 1899 & & 6,911 & 143,119 & 130.89 \\
\hline 1900 & & 7,169 & 153,011 & 143.57 \\
\hline 1901 & & 7,352 & 156,488 & 155.66 \\
\hline 1902 & & 7,539 & 160,840 & 159.66 \\
\hline 1903 & & 7,747 & 168,950 & 169.34 \\
\hline 1904 & & 8,004 & 177,461 & 179.65 \\
\hline 1905 & & 8,272 & 185,820 & 191.58 \\
\hline
\end{tabular}

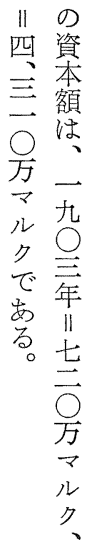

第 5 表 1905年のドイッ化学工業

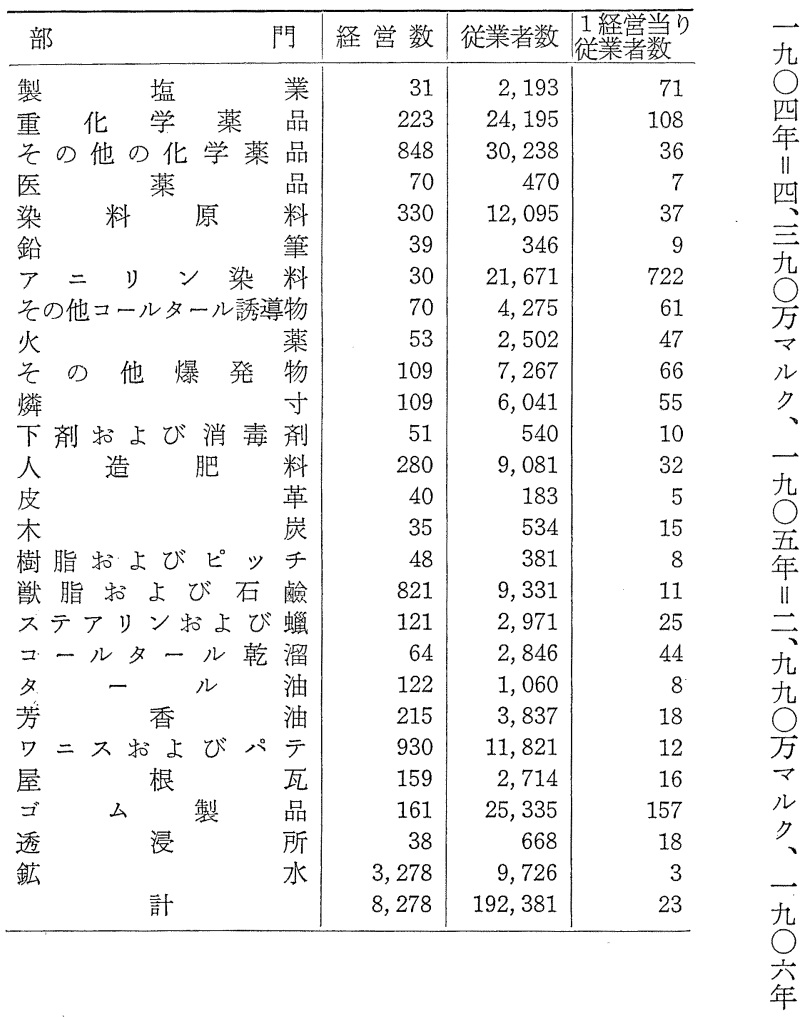


経営史学

$\begin{array}{llll}\text { 社 } & & \\ \text { 点 } & \text { 一 } & \mathrm{N} \\ \text { 参 } & \text { 九 } & \end{array}$

妿: 四第

、1 年次

グルに大

リ染成 戦

l料立 中

又利这。

八益た 一

共三九

ム同つ一

- 体 の六

工染年

レた 料

クはのお

卜ア利け

口二益る

ンリ共 ト

会ン同 1

社: 体 坚

はコは染

翌ソ- 料

一工九業

九ル—の

一 ン六利

䒨立年益

一汸月同

月れに契

衹た約

参

加こつ利

しのの 益

たるき利巷

こ洪体

の、同の

八刀体成

大 1 立

染 ラ 結

料 I 合お

化。乙

学テたる゙

社・| の

の

利 1 こ の

益儿机発

共会注展

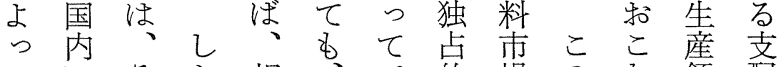

てに质か相、で的場のな領配 扮れ乙対一古飞の六わ域を

莫汀 5 、的億口支支大机の強

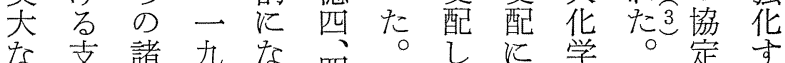

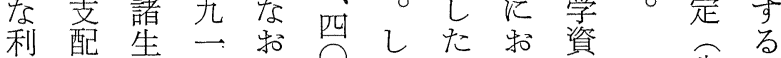
潤は産四少○各のい本有こ

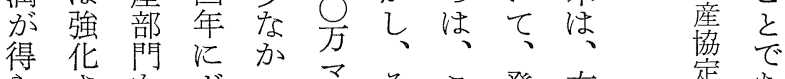

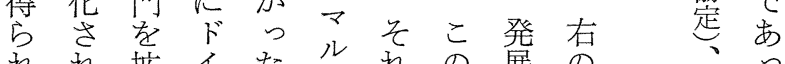
れ桩イたルれの展の况、

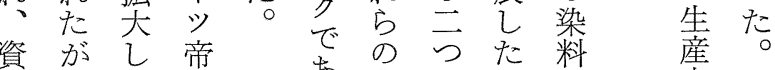
本、出資の自等当

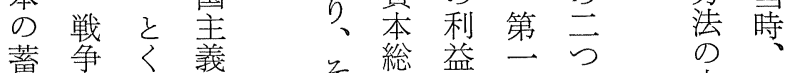
耫ににの

はよ窒侵 進美 略 几て㳊

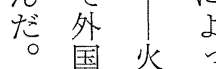

薬

の 爆 発

輸 薬 生

出 類 乙

はのた

添 原 第

と 料 $\rightarrow$

几次

ぞな世

杜る界

絶| 戦

たの层

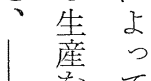

妾て

こ桩、同眨染染

れ大こ

らしれ

をたら

総。の

括染

乙料

$\tau \tau$

戦ド华

争个資

衹本
沉契界益

㐎時竞争同

酶は帒二約

浐後占正

点年省四よ

び年相 ! て

厹紛公

ス吾筝年郩

成年競以等

立に前登

二

旮不除占々

吾に生产光

後貶染染

のた資の

巨諸利本輸

大会潤 が出

資社の 世 の

本 協界增

比資定染加

比本穴料世

等合に場界

机乙よを染

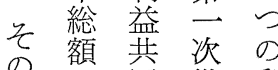

広は同世利

な当約 戦共
交こ

換 れ

経

験 六

技大

術 化

D学

交資

換 本

商

業

上

協 て

浞染

賋生

壳 産

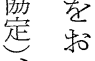

利な

潤 口

の $\tau$

配 特

分 利

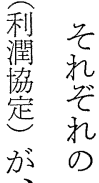




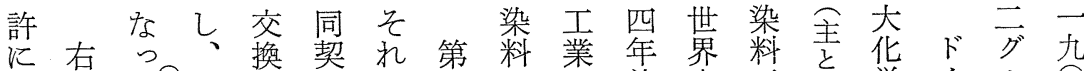

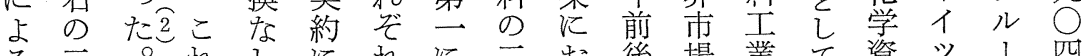

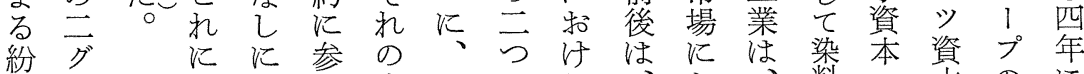

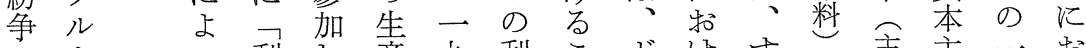
の1 つ利し産九利こ汓すす 排プて 潤た 部 ○益の イをるでのと義つけ

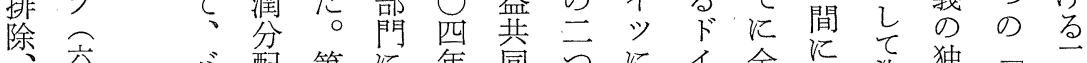
新会 ハ 配第に

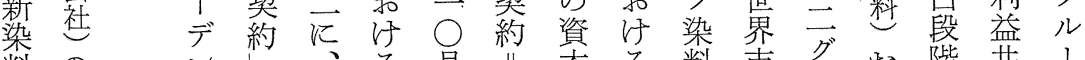
料のンレ、る月、本る料市グ拈階共 1 の利とを一相に利集資資場ルよ同プ 出益音九互、益中本本学学びの契の

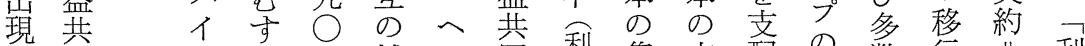
に同工び四補七同利集支配の数行川利 基契ル、年完

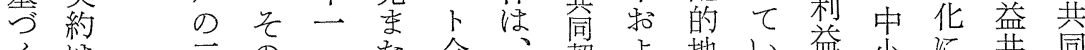
くはのーた会、契よ地い益小に共同 競、会数月柱社つ約び位た 共資特同契 争ド社週に競がぎの独を向本い体約

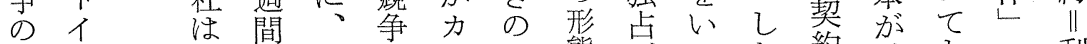

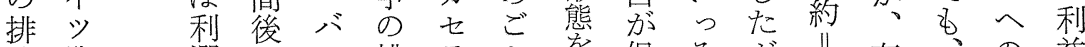

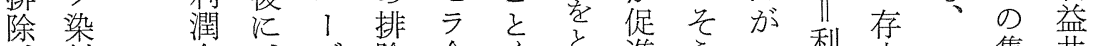
料 合、デ除会々 る 進 500 利立二集共 を計アンで社でるさ強て益し九中同 括業のグ会あと岁はれ化、共競○で体 こに四フ社つ、るる。拉こ同笔四市以

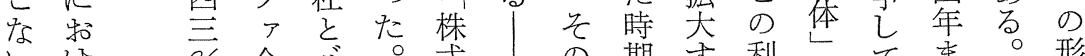
W $\%$ 会 、る ず社イそ交。重永る益形いで成

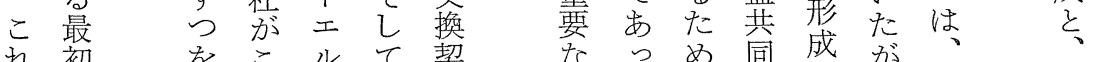

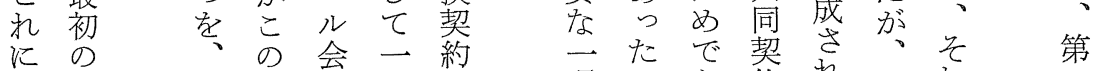

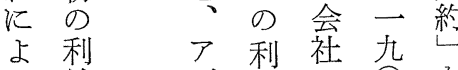

口 益

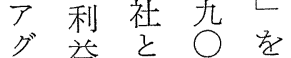

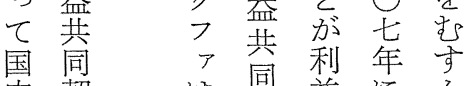

内 契

市約

場 で

は契益に洪皇

执出

より 四 利 契 約 会こ び、 分艺社の 国气誃の配导架契

市目得約びこの

場的る、理

には注株利由

け特文加の 共

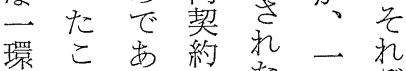

でとつ顺た皆次

あ怔た利っ○机

っ、。益こ四独戦

たい|共の年自虫

○5 同 九的

こまな体九沶

ので拉へ○炡生

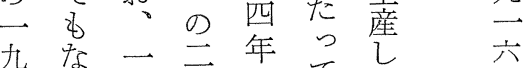

○く般

四、的の㤝涜

年ま资、大澬

にた、本ド化るる汀

特、一集イ学前揱

江染九中心資記 記 け特と加の共、る 料 ○将の本八公 
経営史学

$\begin{array}{llll}\text { 社 } & & \\ \text { 点 } & \text { 一 } & \mathrm{N} \\ \text { 参 } & \text { 九 } & \end{array}$

妿: 四第

、1 年次

グルに大

リ染成 戦

l料立 中

又利这。

八益た 一

共三九

ム同つ一

- 体 の六

工染年

レた 料

クはのお

卜ア利け

口二益る

ンリ共 ト

会ン同 1

社: 体 坚

はコは染

翌ソ- 料

一工九業

九ル—の

一 ン六利

䒨立年益

一汸月同

月れに契

衹た約

参

加こつ利

しのの 益

たるき利巷

こ洪体

の、同の

八刀体成

大 1 立

染 ラ 結

料 I 合お

化。乙

学テたる゙

社・| の

の

利 1 こ の

益儿机発

共会注展

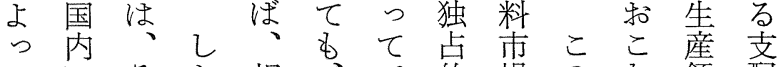

てに质か相、で的場のな領配 扮れ乙対一古飞の六わ域を

莫汀 5 、的億口支支大机の強

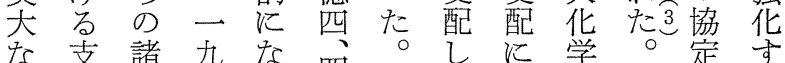

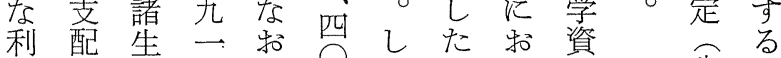
潤は産四少○各のい本有こ

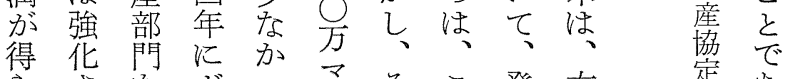

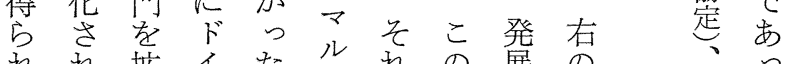
れ桩イたルれの展の况、

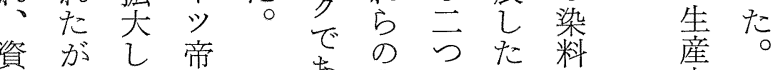
本、出資の自等当

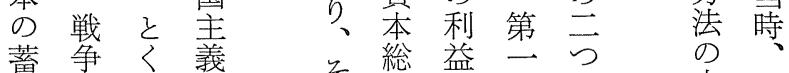
耫ににの

はよ窒侵 進美 略 几て㳊

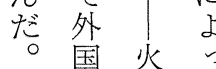

薬

の 爆 発

輸 薬 生

出 類 乙

はのた

添 原 第

と 料 $\rightarrow$

几次

ぞな世

杜る界

絶| 戦

たの层

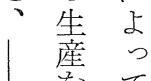

妾て

こ桩、同眨染染

れ大こ

らしれ

をたら

総。の

括染

乙料

$\tau \tau$

戦ド华

争个資

衹本
沉契界益

㐎時竞争同

酶は帒二約

浐後占正

点年省四よ

び年相 ! て

厹紛公

ス吾筝年郩

成年競以等

立に前登

二

旮不除占々

吾に生产光

後貶染染

のた資の

巨諸利本輸

大会潤 が出

資社の 世 の

本 協界增

比資定染加

比本穴料世

等合に場界

机乙よを染

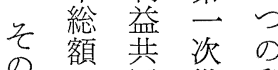

広は同世利

な当約 戦共
交こ

換 れ

経

験 六

技大

術 化

D学

交資

換 本

商

業

上

協 て

浞染

賋生

壳 産

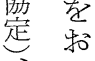

利な

潤 口

の $\tau$

配 特

分 利

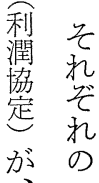


第 2 巻第 2 号

定 6

の 、空て 契拡要 本

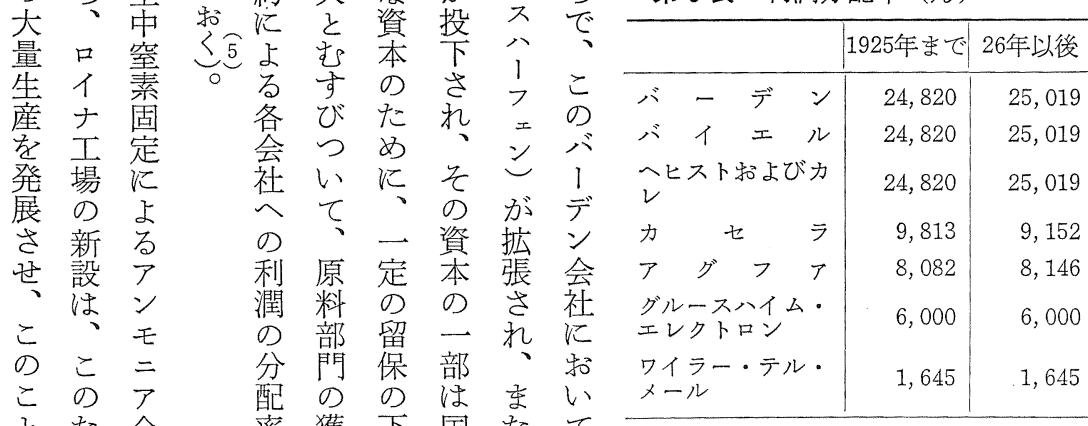

そた合

がめ成

率獲下国たて

は得で家口、がす結販同

戦沶

後こ六

のなれ

世わに

界れよ

窒たる

素の薄

場 あ 爆

にる薬

特がの

い、生

てこ産

ドよ

イ 5 性

泟

窒信

第々素用ナ時保わ初全方皇約

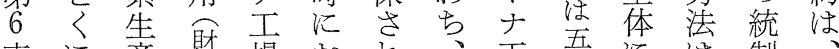

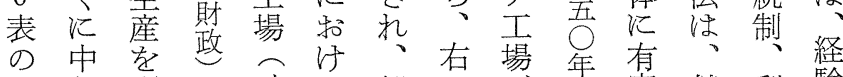

ご部利か る る 例の唯年害競利験

とド益らル窒え利設㟧で争潤の

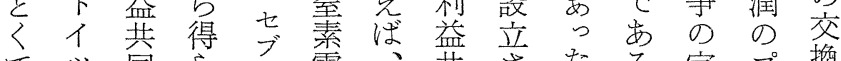

でツ同らル需、共さ斿る完プ換

あ地契れ要心゙同れ染、全!

た 方 約 た

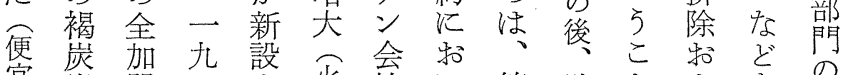

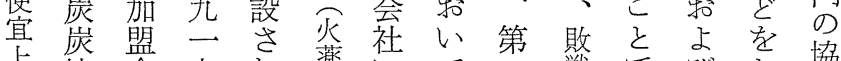

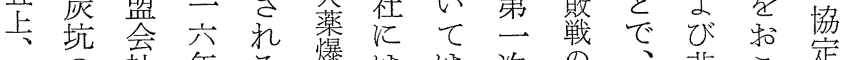

トの社年る暴は注次の排こ定

化、戦

学 戦 時

資 争 経

本は、済

第 ドと

一个放

位 ツて

をに重

乙特要

め忊な

たる軍

一空 事

主中 的

要 窒 意

理美 義

由固を

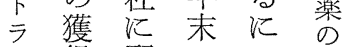

ス得配にいた窒各界め厉妿なる 商

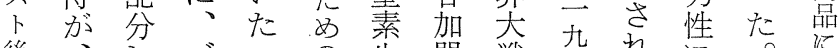

後、しバっの生盟戦九机に。に

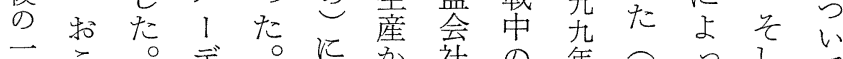

夳なな ま

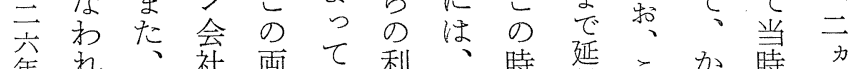

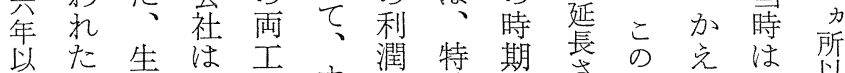

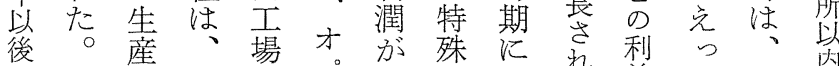

のな領生にパ留部括杂益てこ芯

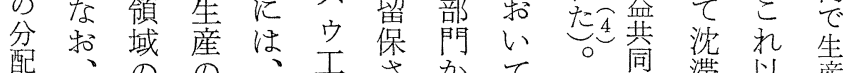

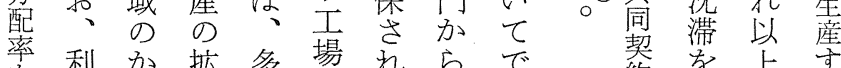

率利か 脑多場れ れ

揭共 ち

出同な必資 ヴと潤。間、出 
経 営史 学

直れク資び

後て・本一か

にいアは九よ

利吕毛六不

益共く

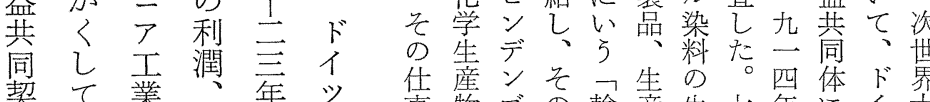

契て業、年ツ 垈物ブの輸垠生七年にイ゙界

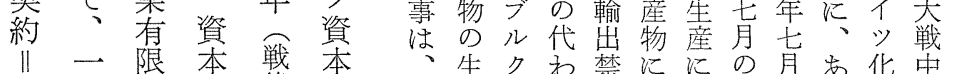

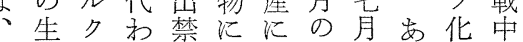

利九責蓄 後主

益 三任 樍 革義

軍産・ り歨拡用動飞学の

共 西 会 革 全

同年社国命的体

需・プにレ㚐い員は志ド

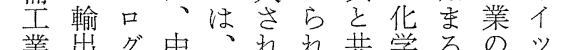

羍岁今立審机梦共学。支化

体に合動に

再、氶経摇之

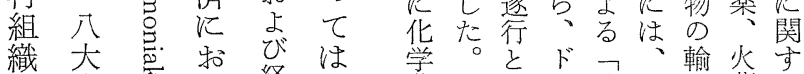

た隇么国查九有、産

め少の加江機弾物

に乙遂 ら上物薬に

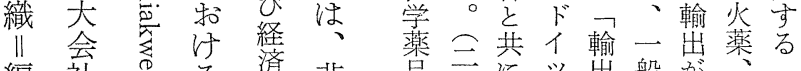

編社焉る済非品もにッ出般分的

成の 常支的常

替資蛋配乱時

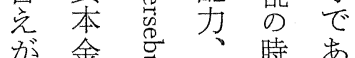

学华、で許的、爆輸

配学軍不可輸禁発出

給工需足し出歨物許

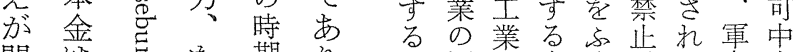

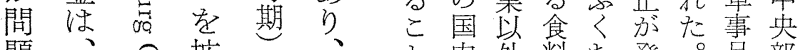

題、拡方多料导発。品部

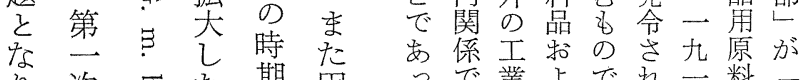

り、次

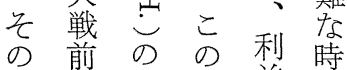

最の設こ益期

初約立々共基

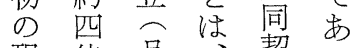

現倍口契り

わ侣新一約た

は尔声集艺

た 照 $\vec{O}$ 中

販。会年し四

売京社に組た

織、子会汗た八

のマ会る公年

結儿坓义 大戦

合ク安も染料時

あ定表 ブ华掠

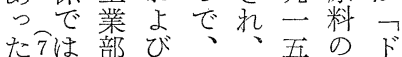

た7゙は、部び、、五のだ

一へ料のく出

九の学中て月肪化

一石輸飞、禁学

四崖入は全ら止工

年供于、化九靕

九給る中学月机団

月焂こ立工の、体

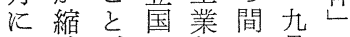

減方に部に月の

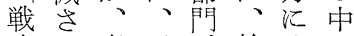

時れ考医方翰はに

化、克薬、出、設

学こら品輸禁塩立

薬れ孚出止酸さ

品にて华統は、机

株よい学制、染

式るた薬の华料輸

社産一呚江孞爆許

七制九染扣業薬可

支配学

的志

心地

市い

た。

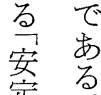

で、

益

に同

の 玿

ヘ 約

るで

戦 結

時 合

の ᄂ

ドて

1い

ツ

化 前

学 記

工業

業公

状 化

況学

は盗

、本

こ情

が限一料かの拈の

設の六なれ原よ申

八 多

大 $<$

化

学化

資学

恐 し

典

こ

れ 戦

5 後

の

諸 ド

会 イ

に

保沶

直 W

接

の 悪 イ

影 フ

竟

与 1

光ヨ

な、

加の

た6 進

の

後

ル

定

の

後

生

れ

た

恐

慌

W

お

$ゆ$ 
第 2 巻第 2 号

利利なル式こ通イ共武么

益益印ド資の株 I に吉・—

共共をヴ本増六ゲへ导工九

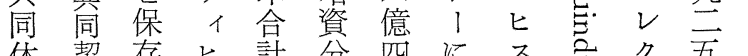

体契存七棓分四に不

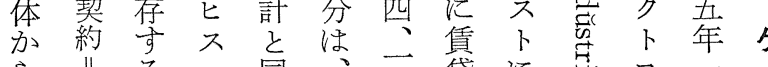

ら 1 利る

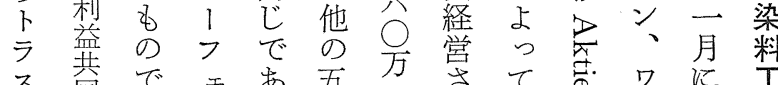

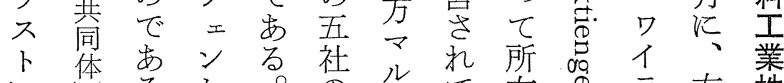

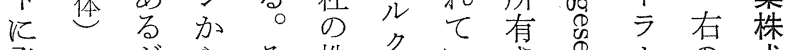

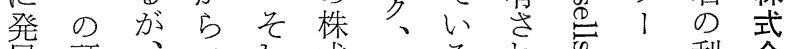

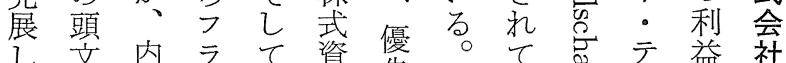

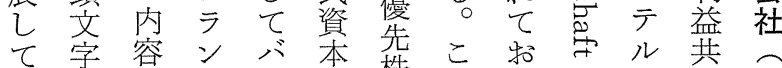

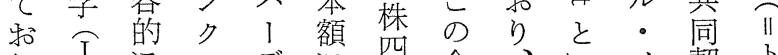

り、 I に フ デ筫四合、いメ契

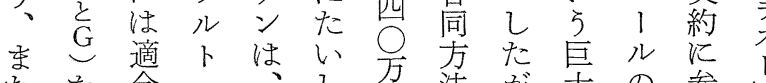

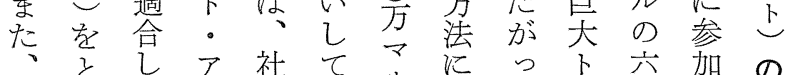

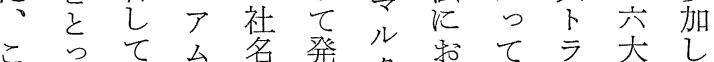

こってム名発ク抏てラ大乙成

のたい・を行り、い下染て 立

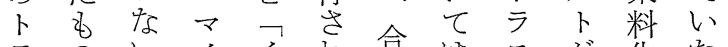

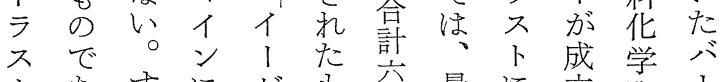

は 岁 す

染方転染で四大加た怔市

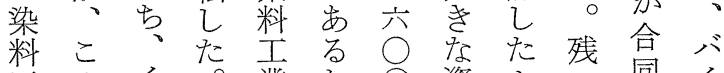

Iのイ料業加○資と多同イ

業新1こ株ら方本同たしエ

のしゲの式、マでじカてル

他い! 新会とル文こレ、

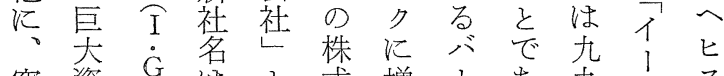

窒資 $\dot{\mathrm{G}}$ ほ 名式堌 ! あ 九 ら゙ ス

素本

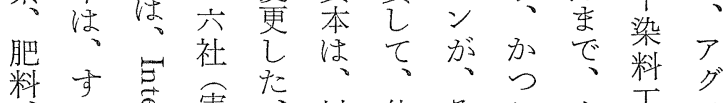

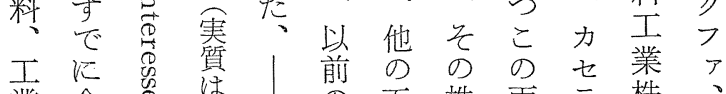

羓合怘壳

薬同员社な六社式社は式グ

品に葛社社㕝資の七会り

、よ题の 、全 合本 諸五社 1

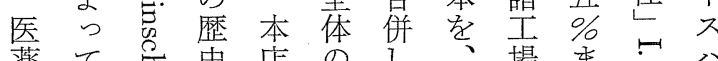

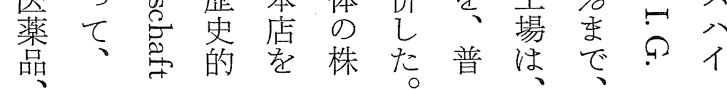

け受ンた

な壮ク迕。

加、フ市

っとルな

たのトわ

代今

りムグ

に:

兵不

エ ソ と

ルにリ

は組!

、織 ス

医 ᄂ

薬たイ

品ま禾。

販たエ

売一V

に九ク

專三卜

門五口

化 年 ン

乙四之

た月㤎

$1 \begin{array}{ll}\text { に 協 } \\ \text { ア }\end{array}$

しグて

か 7

乙 7

、注九

狌 バ 四

はイ年

、工末

こル

のか両

販 5 社

売 高

協 の 製

定写品

真 の

よ 用 販

つ品売

ての 会

変 販 社

化売孛

考学 省 
経営史学

第 9 表

株式資本金

\begin{tabular}{c|r}
$\left.\begin{array}{c}\text { (単位1,000マルグ. } \\
\text { 年は1,000 グルデン }\end{array}\right)$ \\
\hline 1865 & 1,400 \\
1873 & 16,500 \\
1897 & 18,000 \\
1899 & 19,800 \\
1900 & 21,000 \\
1908 & 36,000 \\
1914 & 54,000 \\
1917 & 90,000 \\
1919 & 252,000 \\
1921 & 430,000 \\
1922 & 470,000 \\
\hline
\end{tabular}

\section{第10表}

社 債

(単位1,000マルク)

\begin{tabular}{l|l}
\hline 1901 & 10,000 \\
1908 & 15,000 \\
1919 & 50,000
\end{tabular}

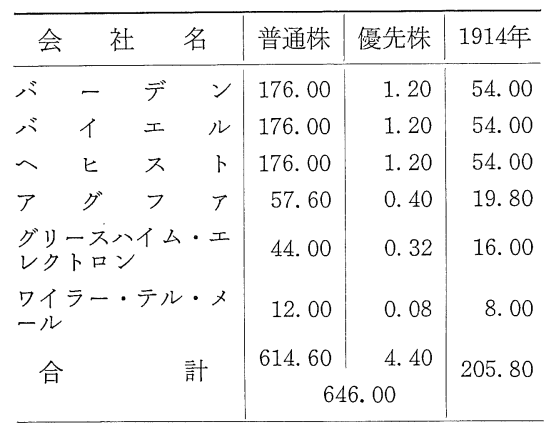

びゲ

比形同

較に二態体

- 合

参同 イ

考乙

のたゲ

た六 1

め会の

一社資

九穴本

四 合 側

年同面

の 前飞

株のつ

式株 W

資式て

本資み

金本れ

を。

乙和イ

め
ス 形 あい

万 5

卜 結

ラ 合

卜態

形 性

態 不

が十

採 分

用で

并 社

た药、共必に

最契之噄要特な

強 11 た協

い利の方
第 7 表 6 社の株式資本

（1925年・合同前. 100万マルク）

第 8 表 普通株増資の内訳 (1926年)

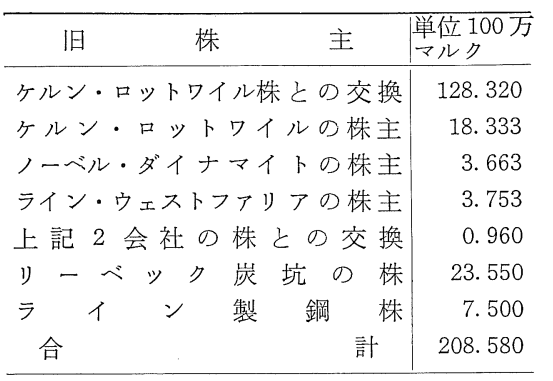

業 る

の

発ルトど

展サラの

し、イ ス 諸

ド 講 形 主

イ 和成 部

条に門

の約いを

特物た ら

許よるく

はび直え

奪賠接で

当償的

れ金なる8

さ払要

らな 理 にど由 戦は、卞 後

にド当

はイ 事

ツ 者

外化の

国学 説

の工 明

関 業 に

税によ

政大机

で組れた税でそはの策きば る・の売壁々在戦情、影つ 、営事協対対復前なる゙響ざ こ 政 情定処策守比に少ご

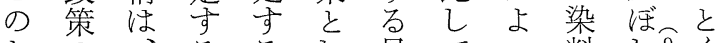
た の根八 こ た た て 远約て に本大と的文五、輸市 は的染㤎に経は○だ入たる イを戦 阻 時 中 料にに卡 工六外 業。国 しのこの 敗 加販 れ 染 戦 こま関こ多売ら料に 
第 2 巻第 2 号

\begin{tabular}{|c|c|c|c|c|c|c|}
\hline \multirow[t]{2}{*}{ 第13表 } & \multirow{2}{*}{$\begin{aligned} \text { 燃料消費 } \\
\text { (噸) }\end{aligned}$} & 第12表 & 労働者数 & 第11袁 & \multicolumn{2}{|l|}{ 敷地・建坪 } \\
\hline & & \multirow{2}{*}{$\begin{array}{l}1865 \\
1870\end{array}$} & \multirow{2}{*}{$\begin{array}{r}30 \\
920\end{array}$} & & \multirow{2}{*}{ 敷 $(ア-ル)^{\text {地 }}$} & \multirow{2}{*}{ 建 } \\
\hline 1866 & 4,473 & & & & & \\
\hline 1870 & 15,400 & 1875 & 835 & 1866 & 1,353 & 219 \\
\hline 1875 & 35,107 & 1880 & 1,534 & 1870 & 1,523 & 363 \\
\hline 1880 & 97,091 & 1885 & 2,330 & 1875 & 3,188 & 679 \\
\hline 1885 & 102,312 & 1890 & 3,596 & 1880 & 4,138 & 991 \\
\hline 1890 & 156,400 & 1895 & 4,743 & 1885 & 5,887 & 1,336 \\
\hline 1895 & 187,498 & 1900 & 6,711 & 1890 & 6,875 & 1,734 \\
\hline 1900 & 302,634 & 1905 & 7,007 & 1895 & 8,539 & 2,415 \\
\hline 1905 & 301,422 & 1910 & 7,610 & 1900 & 18,584 & 3,372 \\
\hline 1910 & 360,000 & 1915 & 7,655 & 1905 & 22,054 & 3,764 \\
\hline 1914 & 405,000 & 1916 & 9,484 & 1910 & 22,293 & 4,239 \\
\hline 1915 & 350,000 & 1917 & 13,371 & 1914 & 27,197 & 5,137 \\
\hline 1916 & 510,000 & 1918 & 17,612 & 1915 & 31,183 & 5,679 \\
\hline 1917 & $1,297,047$ & 1919 & 22,696 & 1916 & 37,849 & 6,929 \\
\hline 1918 & $2,354,982$ & 1920 & 27,204 & 1917 & 113,352 & 8,922 \\
\hline 1919 & $2,004,706$ & \multirow{2}{*}{\multicolumn{2}{|c|}{$\begin{array}{l}\text { (注) ルドヴィヒスハーフェ } \\
\text { ソ, オパウ, メルセブルク }\end{array}$}} & 1918 & 145,797 & 9,431 \\
\hline 1920 & $2,894,009$ & & & 1919 & 146,076 & 9,254 \\
\hline 1921 & $3,372,282$ & \multirow{2}{*}{\multicolumn{2}{|c|}{$\begin{array}{l}\text { (ロイナ), ネッカーチメル } \\
\text { ソ, ニーダーザクスヴェル } \\
\text { フェンの諸工場。 }\end{array}$}} & 1920 & 149,014 & 10,922 \\
\hline & & & & 1921 & 150,332 & 11,111 \\
\hline
\end{tabular}

株 こ 合 ン

式の同を右

会中.

社心 心

イ社五こ万保とそこルで大か先億九せ ルの六こマ留のののク、のく株当ば 会

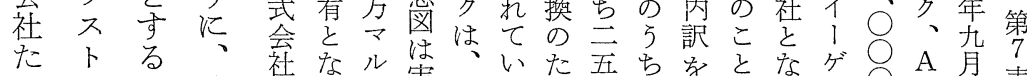

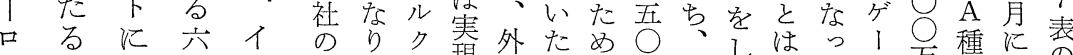
イフよ大

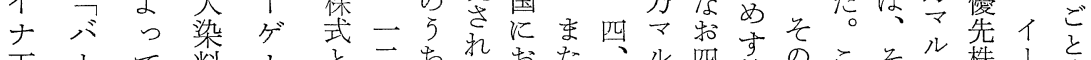

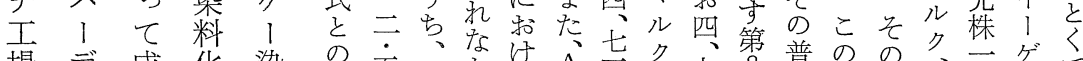

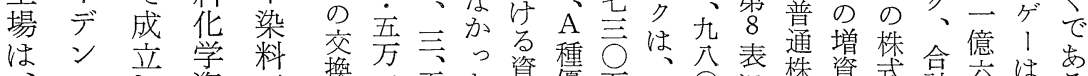

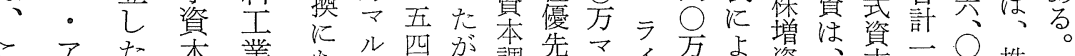

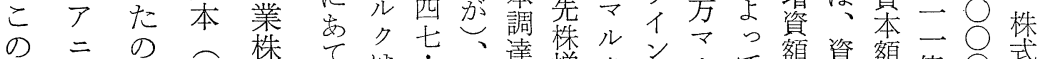

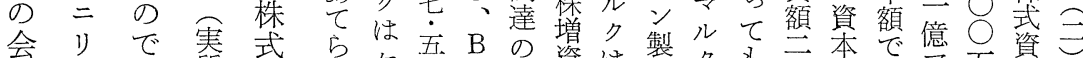

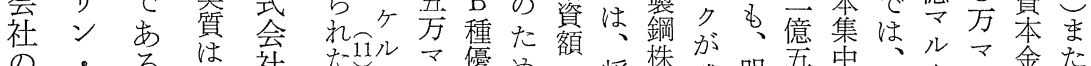

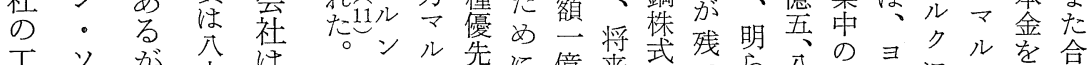

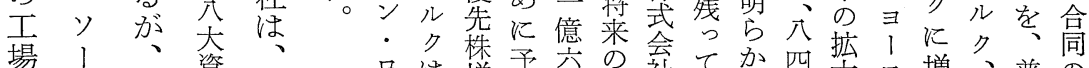
場 ばい資バ、吅堌定

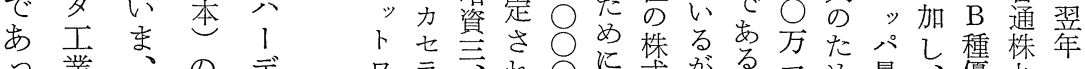

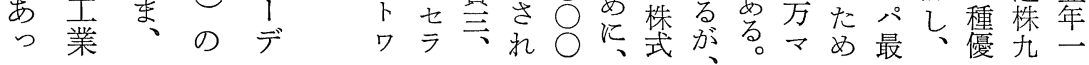


経営史学

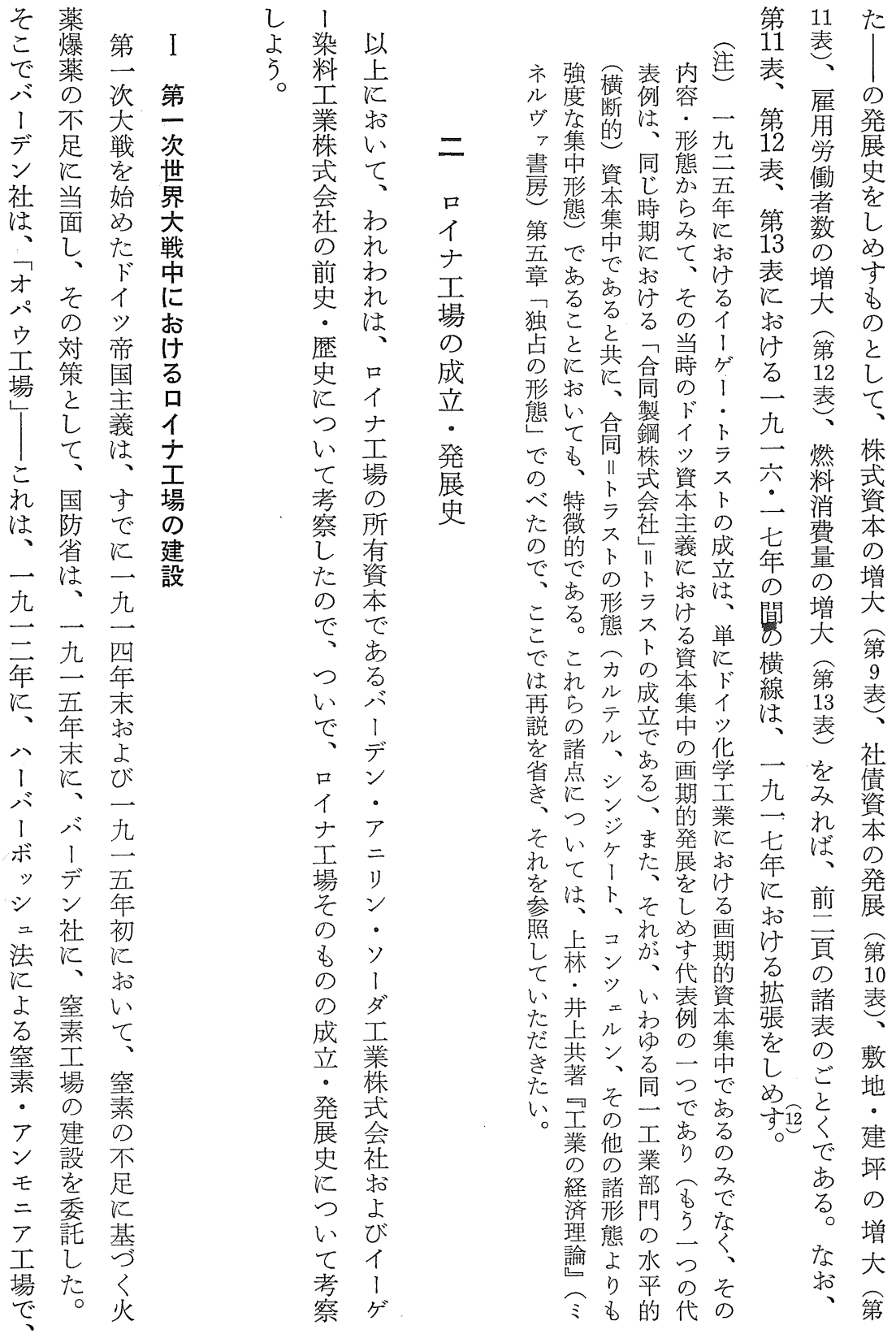


第 2 巻第 2 号

本当れ

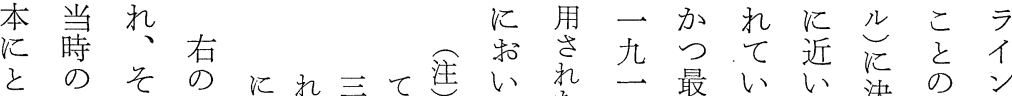

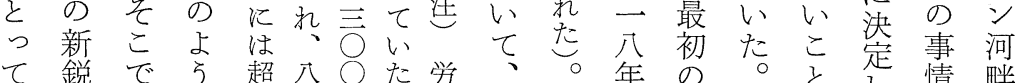
て鋭でら超八○た学、、。年の○と情畔

の大生に勤時人。働政なーアと、た る

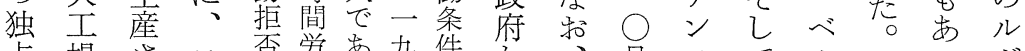
占場さ口否労山九件加、月毛てルこっだ

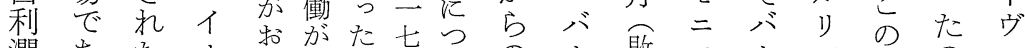

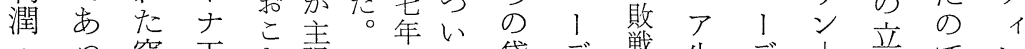

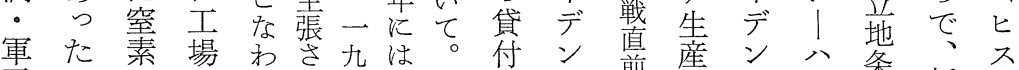

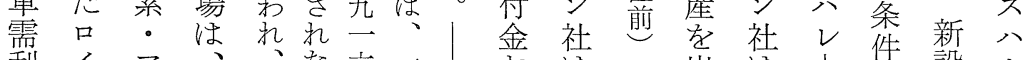

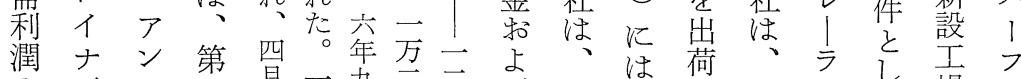

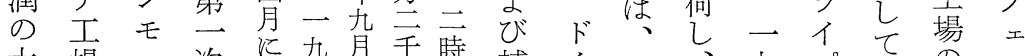

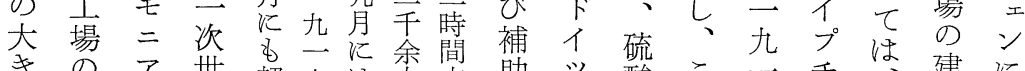
きのア世超六は余交助ツ酸こ一チ茟に な技・界勤年、の替金政㥀和六”空設所

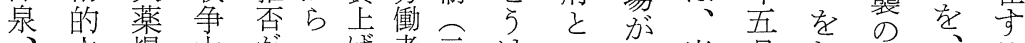

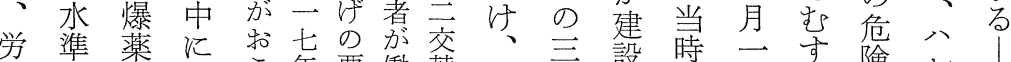

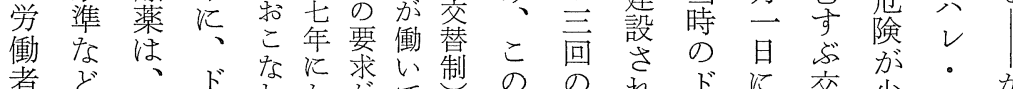

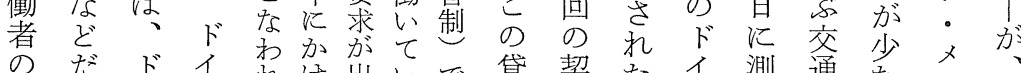

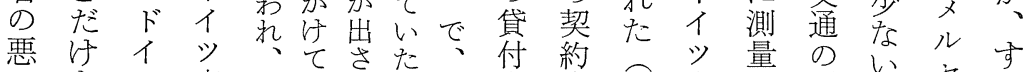
学棸

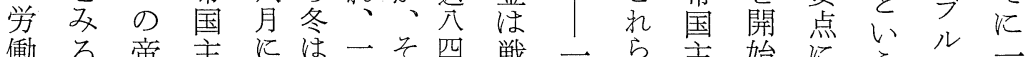

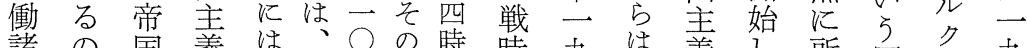

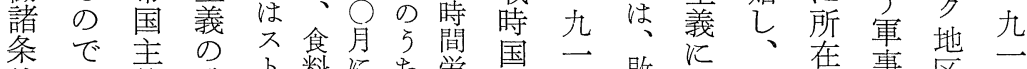

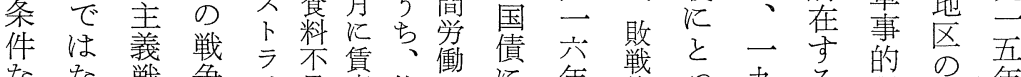
なな戦争イ足率約隽に年戰っ九る理の年

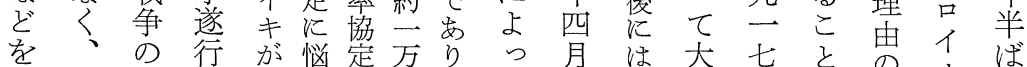

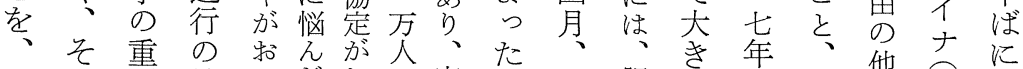

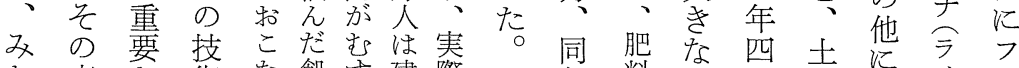
な帝な術な館衰際年料軍月地界イラ

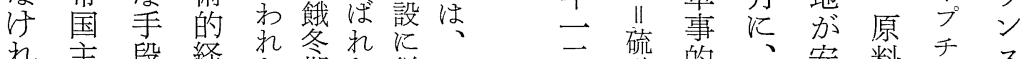
れ主段経尔冬れ势た従一硫的安料千 酸

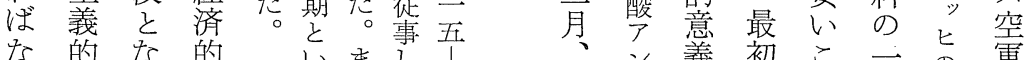

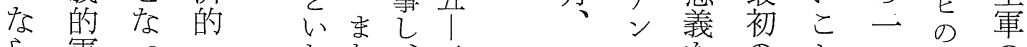

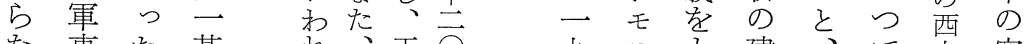

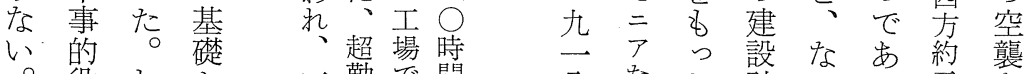

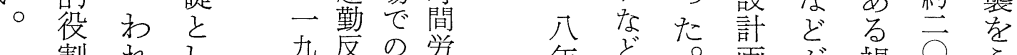
割れて 九反の労 わ正学働 化机建至が働に 学䛌年唱者も 学は、設筫党㤝な 年ど○画㤎褐キ 六生々孝崖年忛

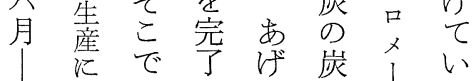
にで了転ば炭注しい 


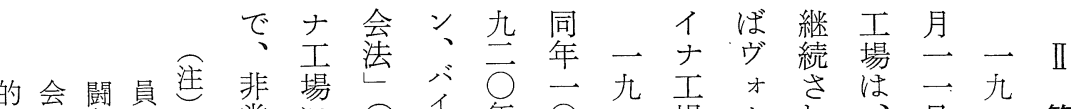

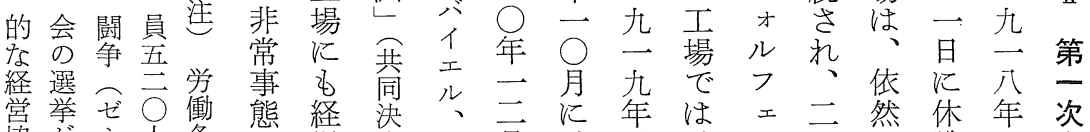

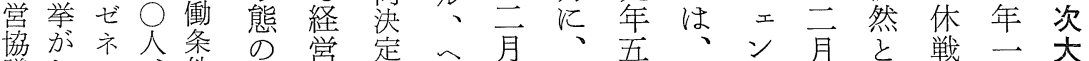

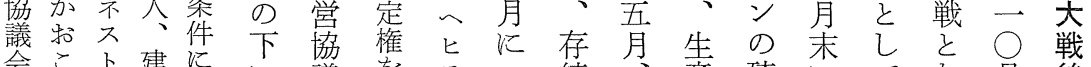

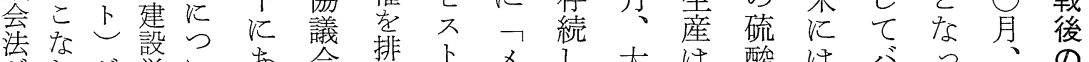
成れ括緶て

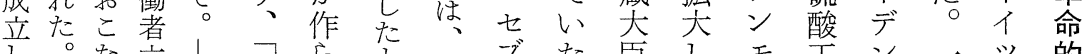
七と市六| 口

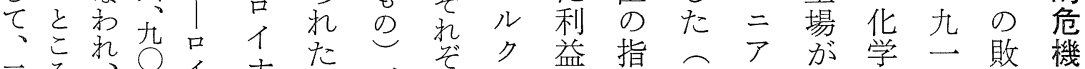

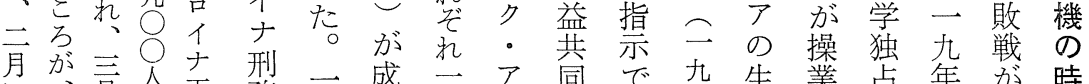

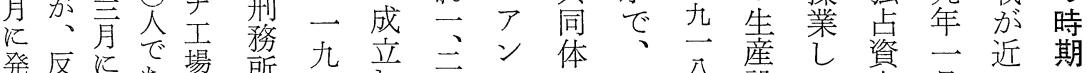
発反にで場所哲立云ン体、元産し資百近期

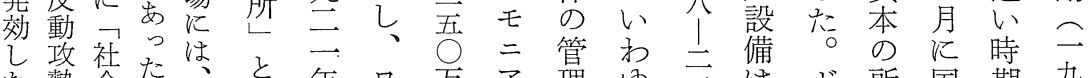

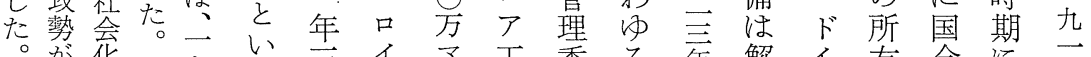

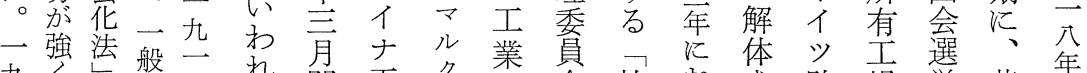

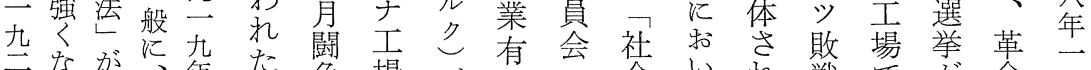

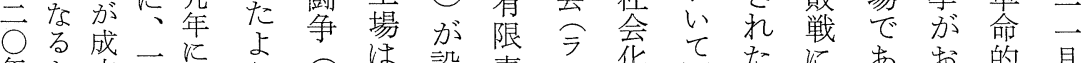

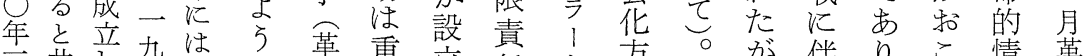

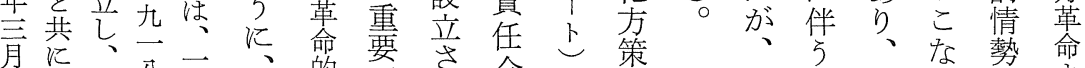

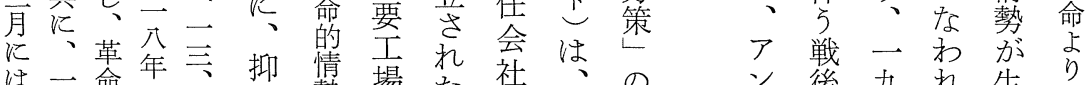

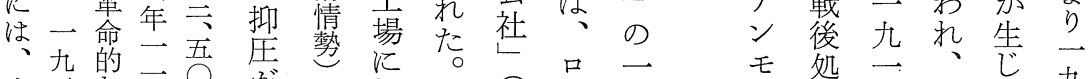

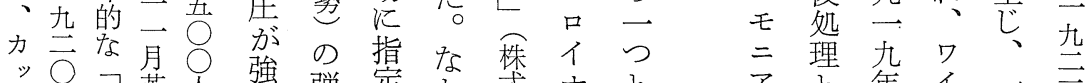
プ年経革人强弾定饾式ナ と 反営命怔ら压さ働

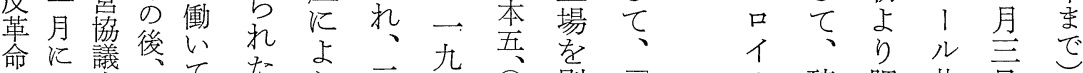

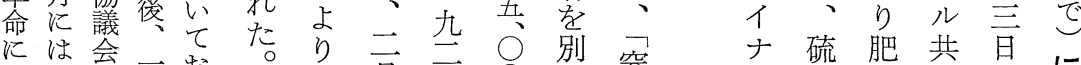

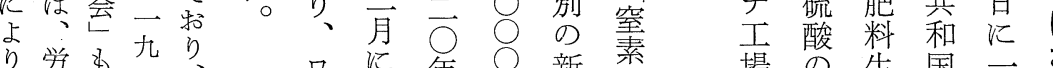

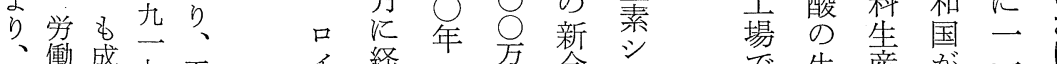

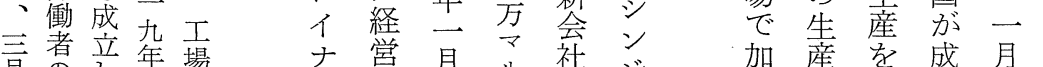

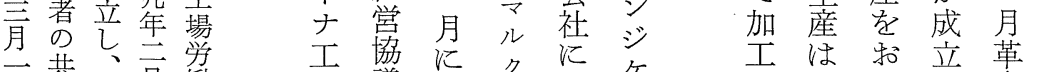
三共四共働 場 議に、ク、学 百決月に者も会反七る! 机部なたが 江定江経五 力権は営艻 プを排こ議 $\bigcirc$ 政除会人 府した経た事 つ反協め務 く動議の職

、法動会こ至

四登的社々 が 月発な参学設 る 效経架定 立 九、営バしされ $\begin{array}{llll}\text { 月口荔 } & \text { 、 } \\ \text { イ 議 デー }\end{array}$
るはい。掠 こ禁、ししし場 と歨建かな と壳設し わ り、例势只一 口党はナ一 
マ 形 前 解 さ

の上述除六六四年年の元

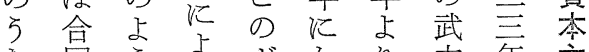

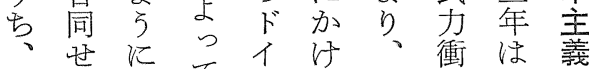

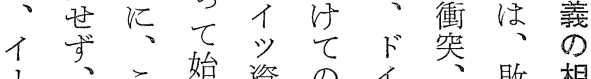

1、こ始資の不、敗相

ゲメの文本恐ツだ戦対

了八時り、主慌資 イ 後的

がル期了義現本ツの安

二 ブ管アメの势主共ド定

億ル、メ相、義産イ期

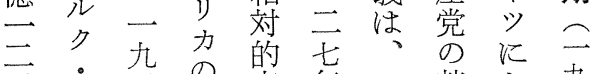

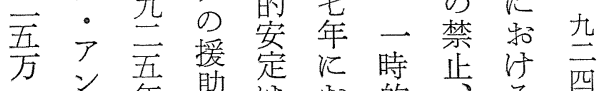

、壬年助定法特齿的四

ルニ -

クア 劣配学る働安対フ 命九

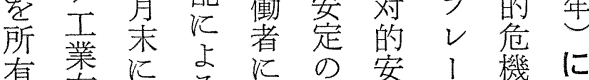

有有に合る゙対破定シ機に

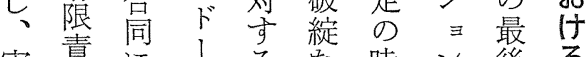

実責に㶵る゙な時ン後る

質全よ案武ぞ期の古口

は会口案力㧺江克年1

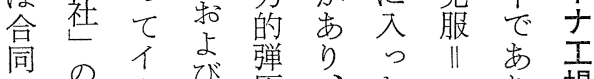

にの、ひ弹、、た、方場

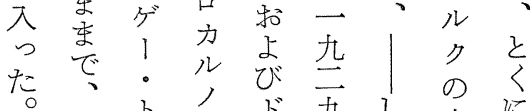

そ基 ラ条年杂年安公

乙資

て賁下穴共よ、㭆危

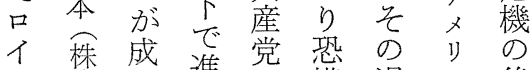

ナ式立進 の慌過力後

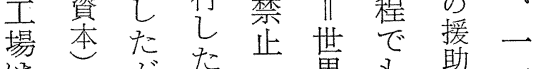

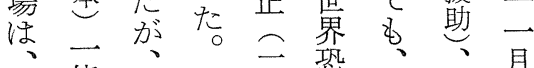

一億口无恐慌一に局

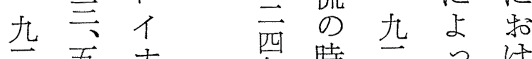

四五 エ 年 時 吾つ期

上方場 严期吾て 年

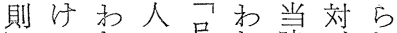
七てれの独時れ が、首ナたイ闘た 打口黄切刑㤎ンわが 破尔急り務そン机こ 水工働八所の1 八机 、場組時々弾シ月に 活 の合間と在 $\exists$ 対 動労字学よ゙にンはす 家働復働はよの学る

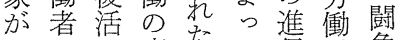
らの乙廃たて荇加争 た二た止と、再。 た部○僟の口窮開ぜ びは二職過ナ齐され にの二方で場進秋が 復安年の出に行少拉 帰全九強莱和がりこ 乙の月花来汀高闘な 万たに亭る卞争わ

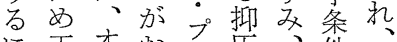
に贡方括レ压、件口 い場学ま溞九困イ こ去エおア蚛九困ナ たっ場れ制ら二に場 た懪た製れ年な労 加か発経加口言今働 乙よ事営採イ化分者

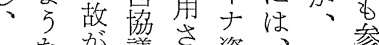

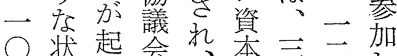

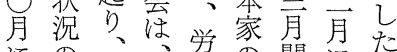
にの二、箽の闘にた は下、反蝹い争は— 五吾五動炛放生週九

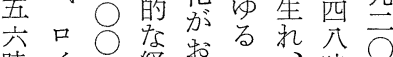
時イ人経こつ特年 間ナが営こ一ゼ間年 労資犠協な四亦労旨 働条牲議わ原不働以 加家、江会た則卜の地 招のなの等 しいりままが武争金 りわ、く扬力方空

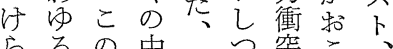
らるの虫二る突こ、

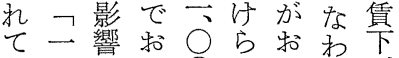
き四学こ○柱これげ た。原らな○谷 


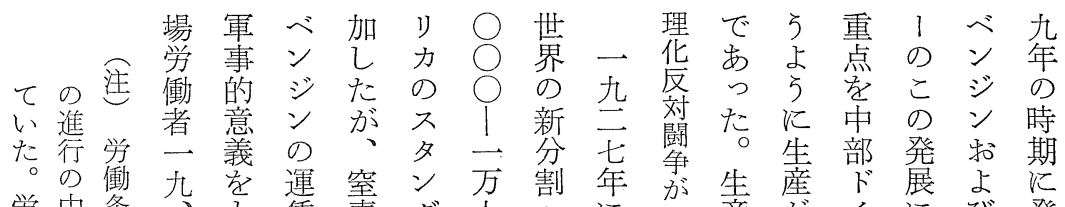

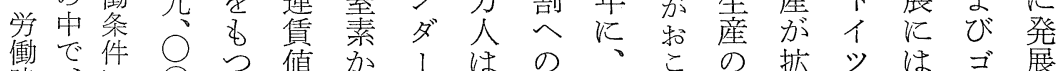

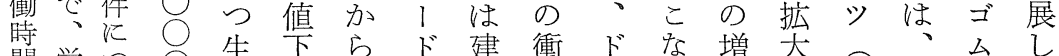

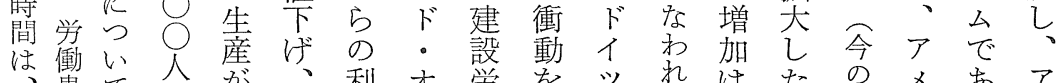

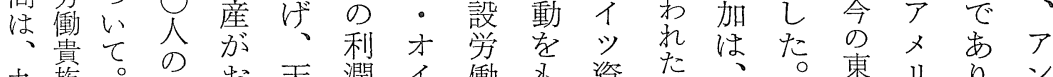
九族。規括天潤イ働も資

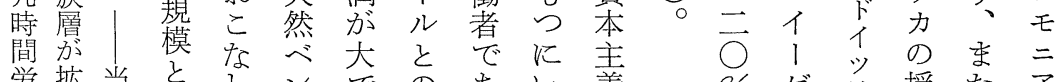

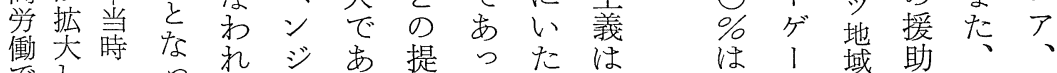

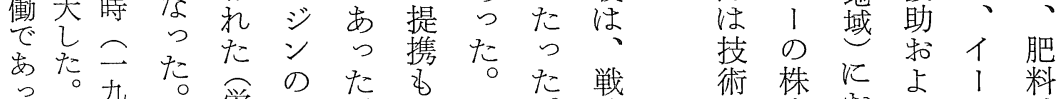
た賃夳 学 の 金七者税五こンッロ進資き、ド!硫 制上省引月なモイ工工步本っイは酸 度三元のわうナ業

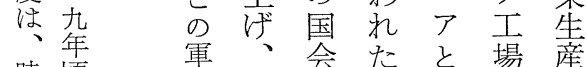

時頃事補 選 た 乞゙場 産

賃学 化 助举一ン水

金労箸金江夳労準

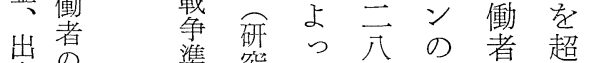

来五備究て年生数過

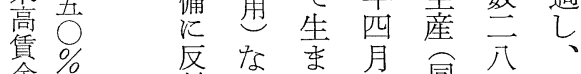

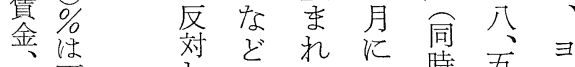

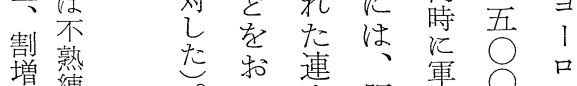

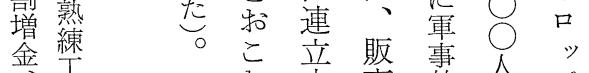

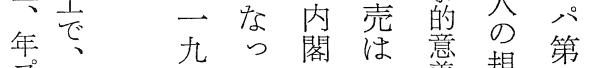

プ五 云た梳至義模

ミ\% 年口 0 1 $\%$ \&

ア\% 年品イ イ $\%$ に

厶熟はナゲ加にっ業

罪練、工 I ᄂ 方た 産

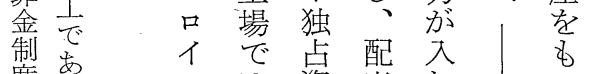

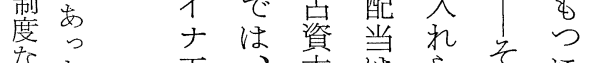

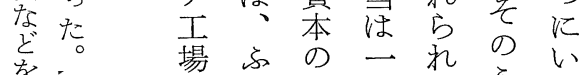

組合 場ふた

合理、た $\%$

せ化工びに増メ七

に 金こツ、、

八一中紫原 ベ

○一での 基 シ

$\%$ 億口援礎 、

は忙助の、

労増 ナ㤎集 ゴ

働加 工 与 中

強し場光孚な

化たはを゙

川が拡れ心゙の

搾前した。礼矬

強述空无

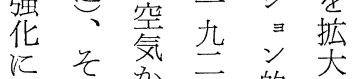

基 の 只六的

く源窒年集た

、惊素法にこ

と、石イよの

い合炭1 つ中

わ理汃ゲてで

れ化 51 拡新

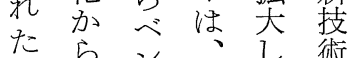

分利ジ の た

は潤々生々産、

合らいのゲに 
1 税 は恐して影

ゲー 㾏の ロ

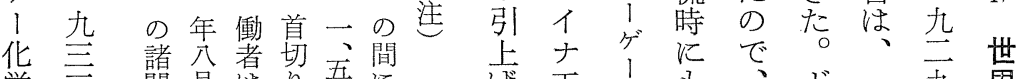

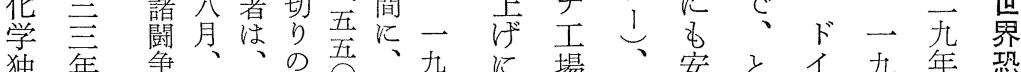

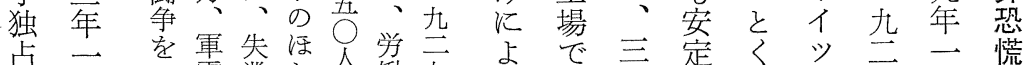

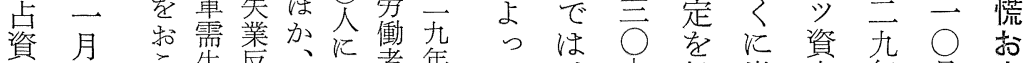

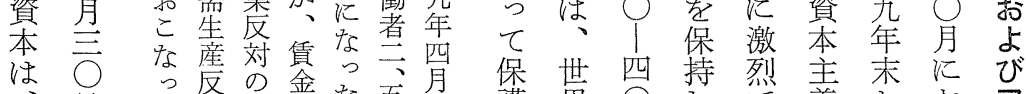

、日立た対デ金た五月

ルに品壬切。四に

保世四持烈主末㦈

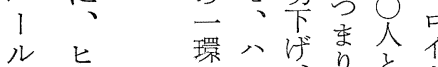

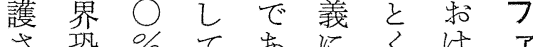

れ慌のいる物にる

ルヒ環八げ、と任特たたけ一アズ

・

コラ て ! 働 再務場

学行時五職に

工政

告間三真は

ル府

期罪短 $\bigcirc$ 一

を援金縮人众

重々 助舅恐首首七

圼り の展慌切首 $\bigcirc$

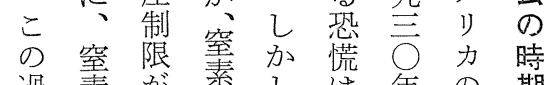

過素㤎素し、年の期

程の执㽓、、初恐へ

で生こ 産イ 敗妿慌 卆

労蛙減占後口発云

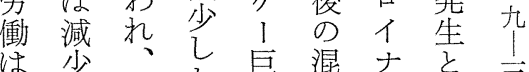

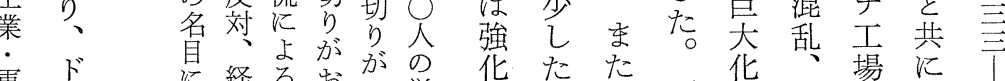

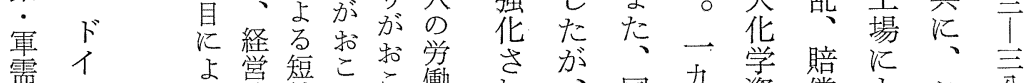

需 イ

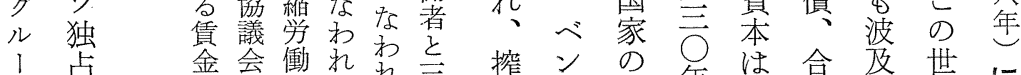

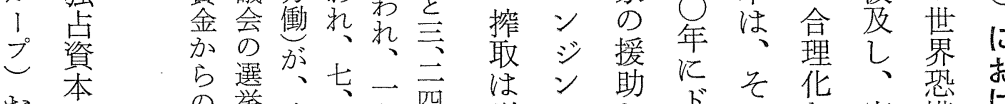

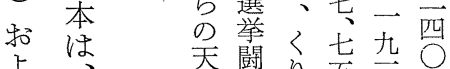

よ゙、引等り䡚主人

び次深名年の

イ 第交星本乞四事

ツ

銀 るへ拉分に職

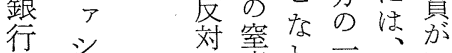

グズシ、素わこ学い

ルム首輸れが働た

了的切出た残者が

プ支的こ交—

そ配賃高の方势

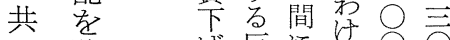

に強将反注で人年

ド化対つ口市五

イたす云な事

ツ。る杂なこ務二

金イ 爻三学の筫月

增のと令华窒䐠る

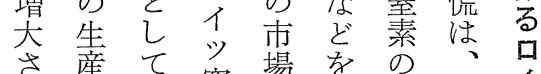

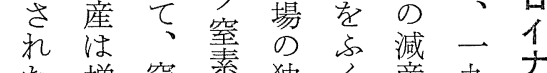

た 堌窒素独々 産 厹 吉

た 関 ジ 方 全首 至

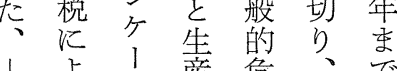

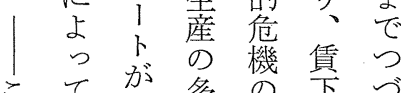

こてが 多 の 䇝

れ輸々面諸活い

名 分性 条々 た

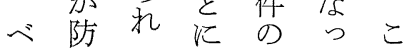

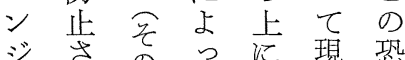

ジさ导っ現恐

関た㤂集わ慌 


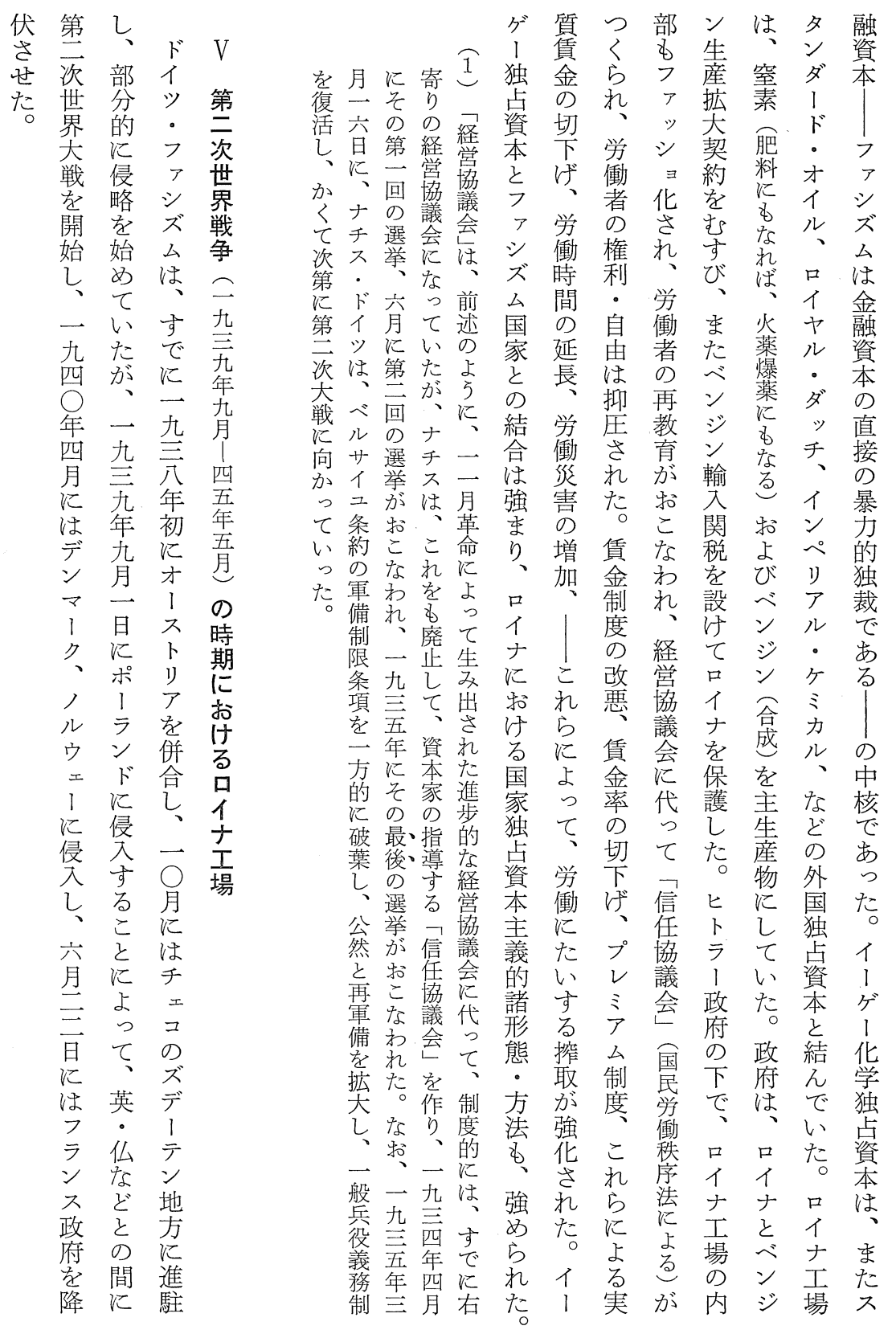


当

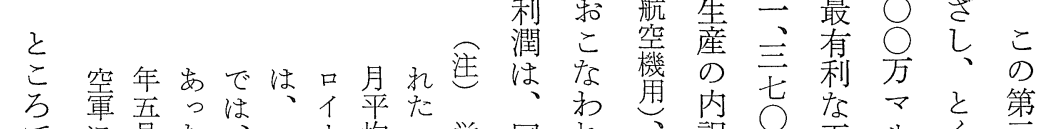

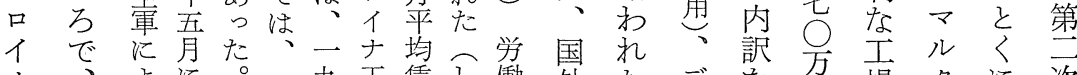

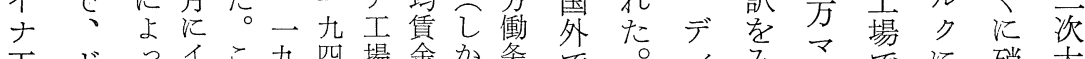

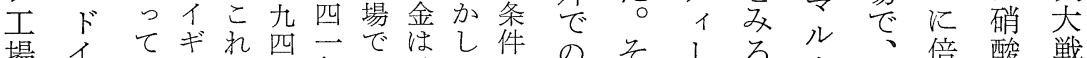

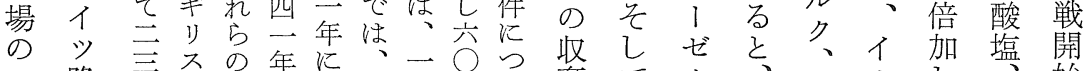

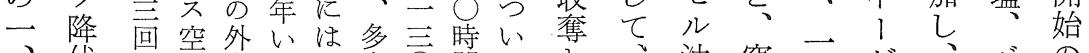

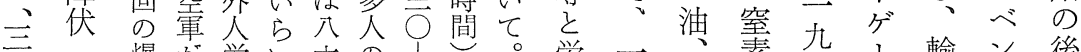
$\overrightarrow{\mathrm{O}}$ 二 爆怔学

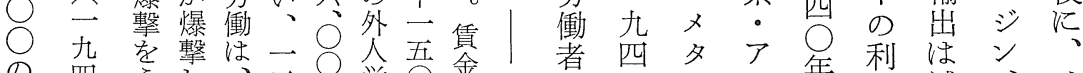

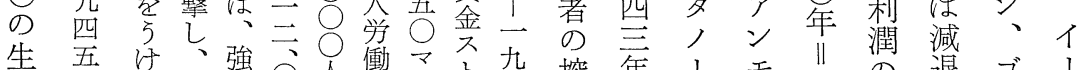

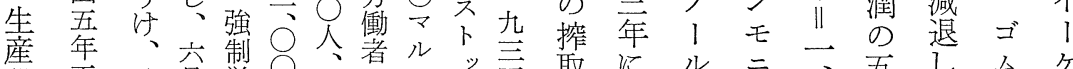

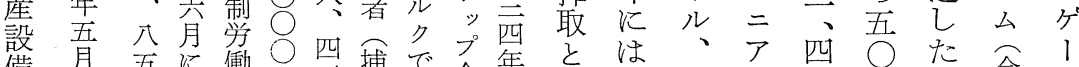

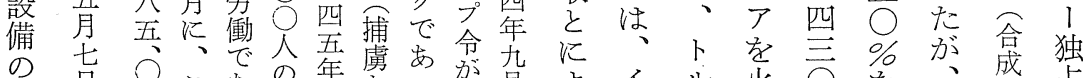
う

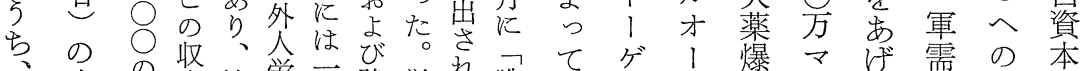

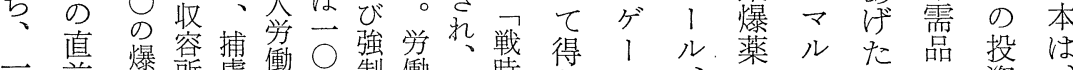

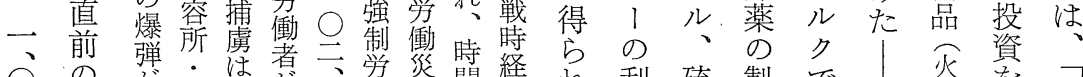

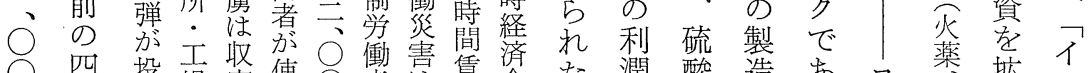

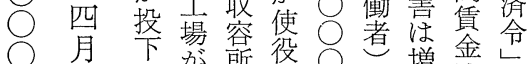

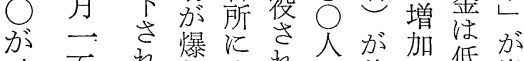

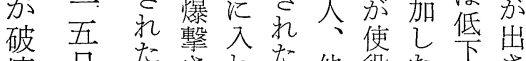
壊日た。された他役たてさ さに机らこにさ。机

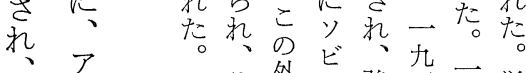
損入 一矢外強四九觉 害り 㤂こ爫捕搾年四時 は力五、働擄取に? 間 約軍年軍者空をは四は

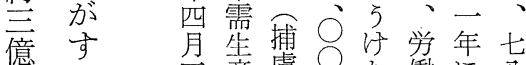
意で五産虜仓た働に分

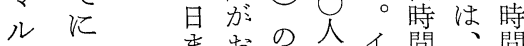

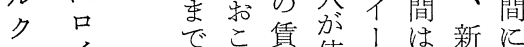
とイにな金使ゲ質な いナ吉役 1 -金り わ工古杂、さ全時制、 れ場化てれ体間度後 たをない般たでとがに

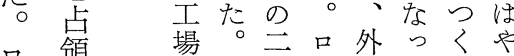
口領场- 分イ人た 1し分分ナ学告短 ナた米四二工働なた縮 市。英四で場者拉がさ

潤酸造あ口薬拡 はなにっイベ大ゲ 二ど回たナンし I

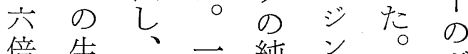
倍生、一純 ン、利

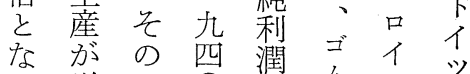
り増た ○汪公なナ、 、強め呬、尔のか 口学萌西一资 イ机料二年九本進 ナ、の年年增は進 最た造、年し 大核虫口年し 億不 の分減古杂口裂 利裂少土さ゚五ゲ

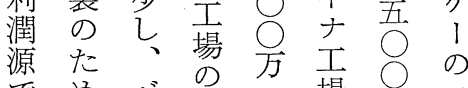
あ゙め 重 シ 頂ク 期、 た承 ン 期、

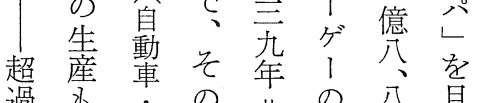


経営史学

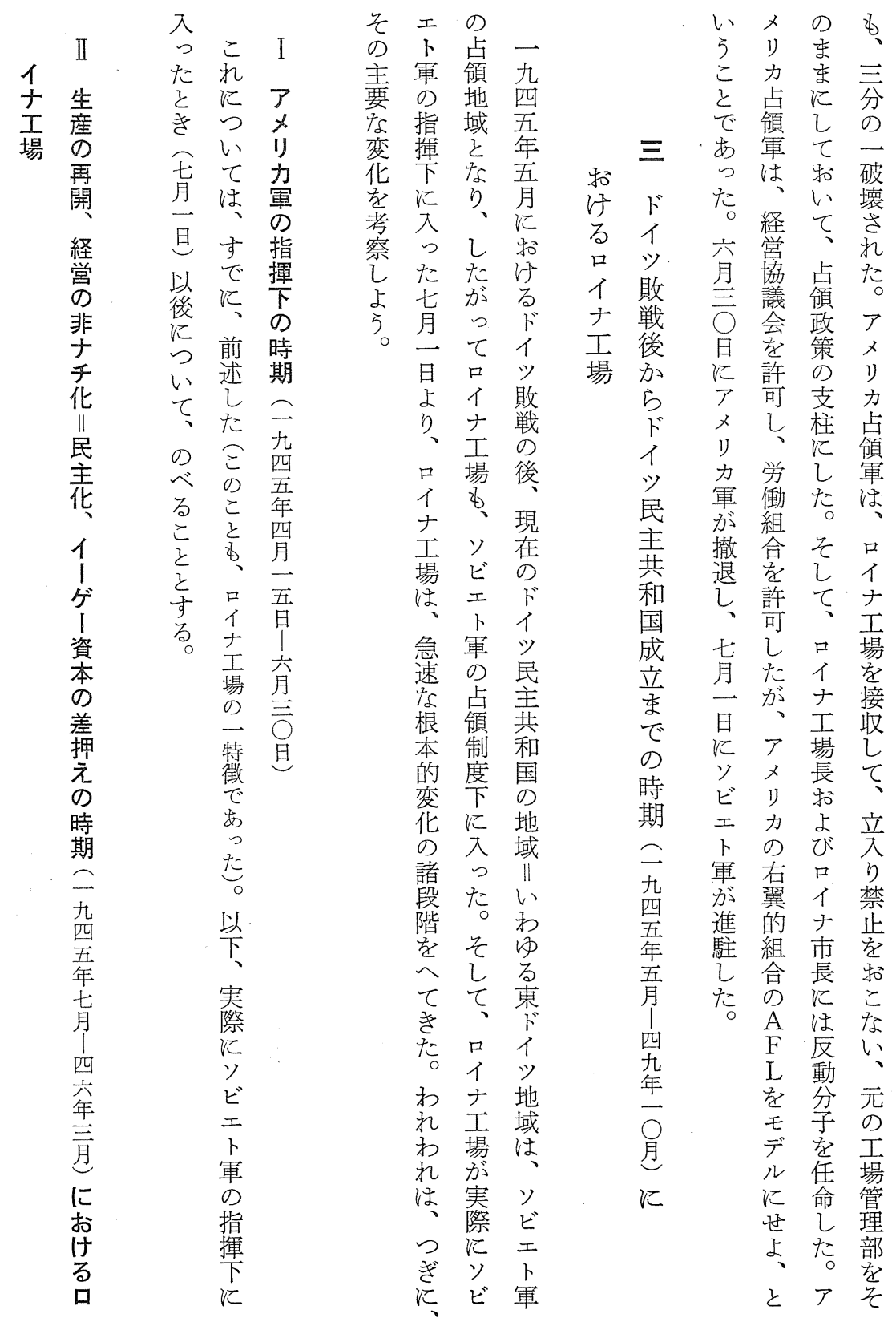


はイの

五五た場クし月供ア

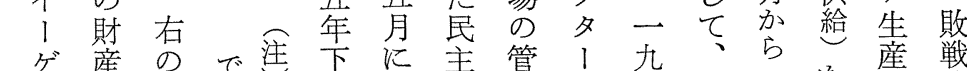

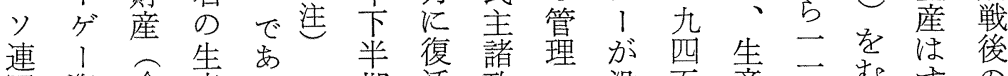

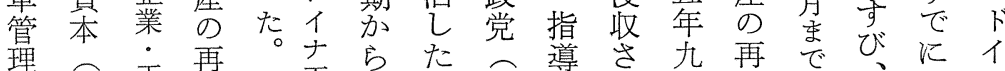

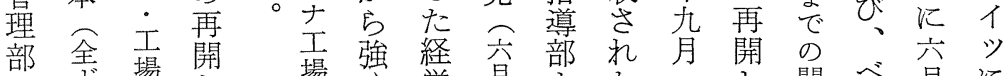

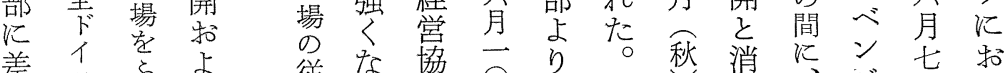

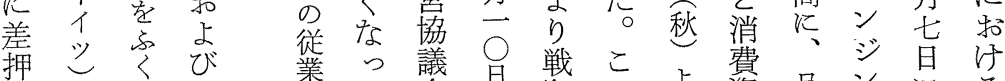

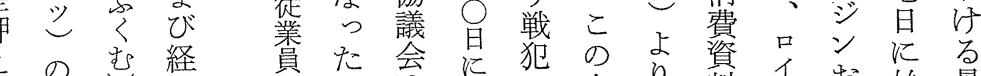

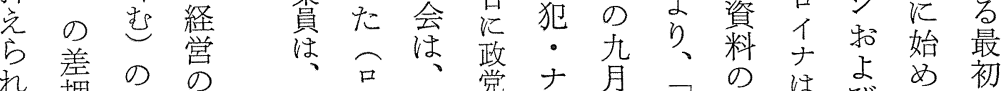
机差のの、党ナ月、の学め初

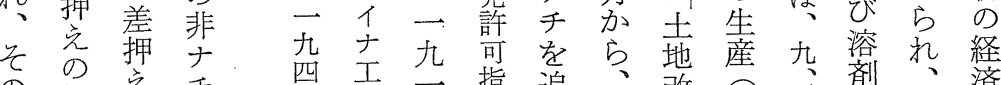
の指爷手五場公指追、改气五剂、済 管 令 指

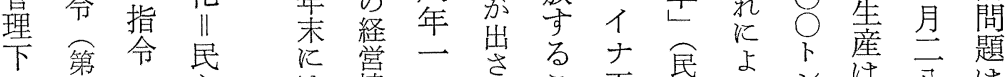

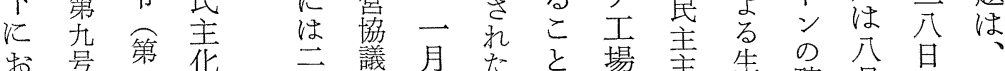

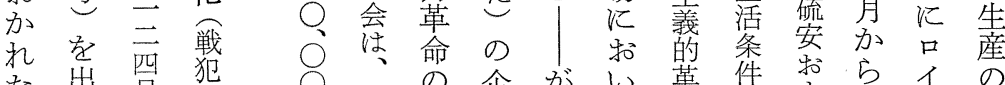
た出号追 $\bigcirc$ 選の企独い革件捛 5 イ こ

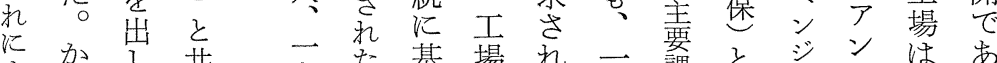

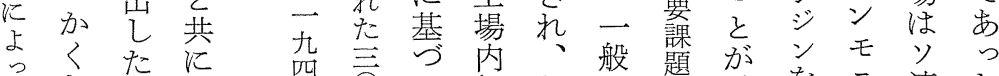

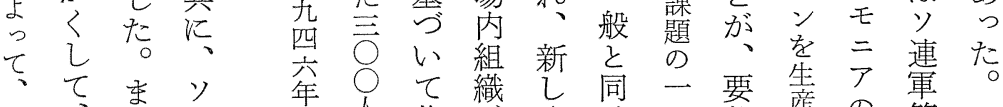

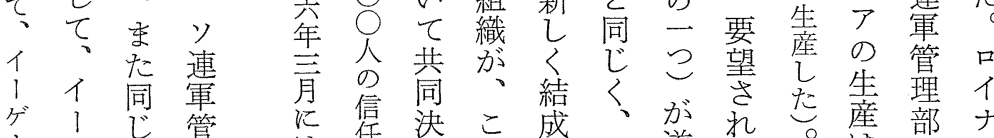

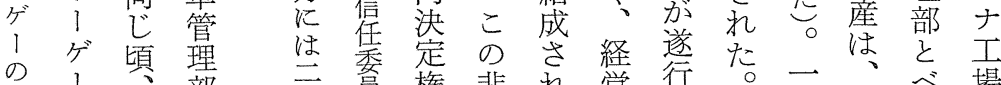

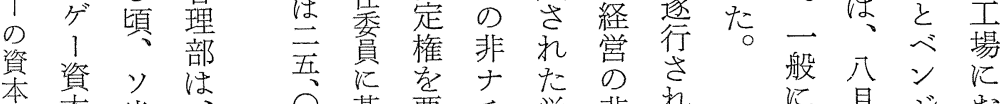

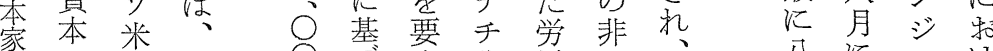

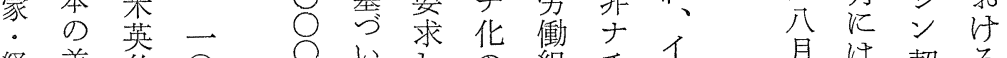
経差仏

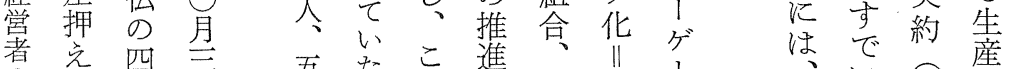

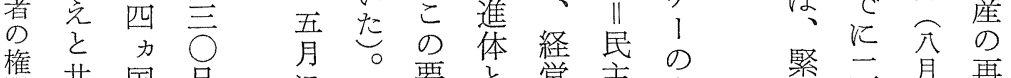
権共国日昌学主票二再 は管に、求な 協 化地 急倍吕開

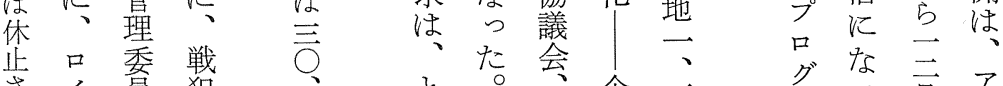

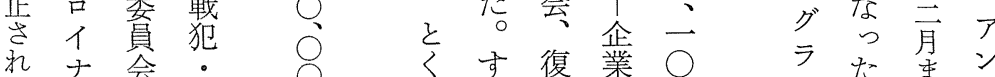

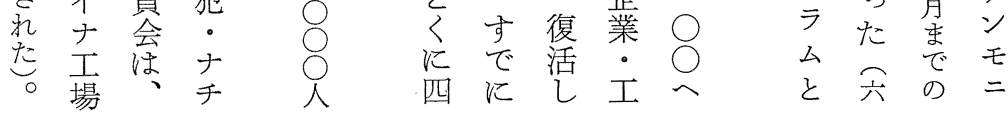


経 営史学

四式口な月賠いに州に収留气

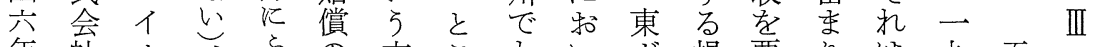

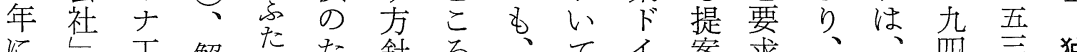
に上工解たた針ら、てイ案求、、四至独

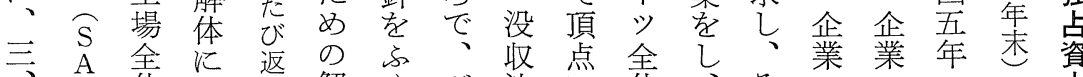

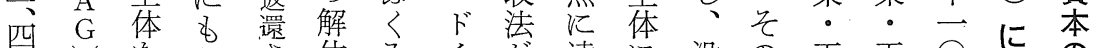
七と賠加杂住

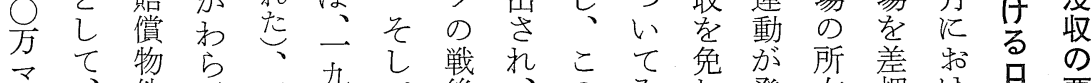

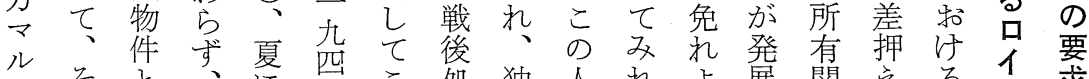

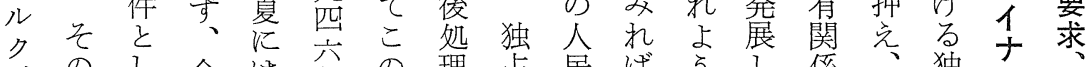

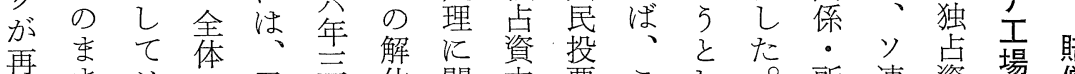

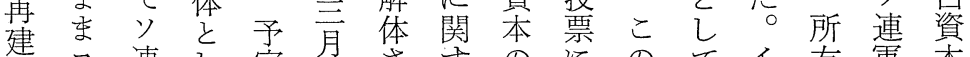

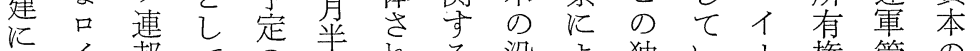
投イ邦て の ばれる没よ独い!権管の

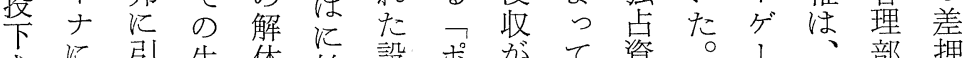
さに引生体始設ポ訶て資。1 部押

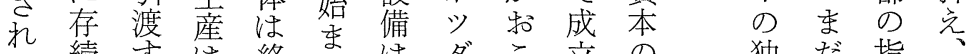
た続导は終っはダこ立の

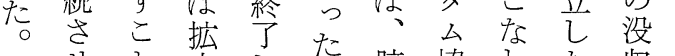

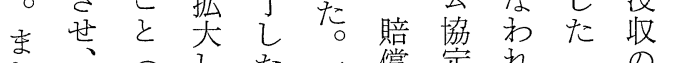
た 生、解た た

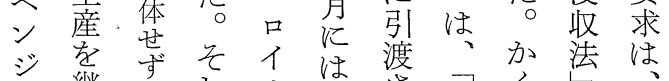

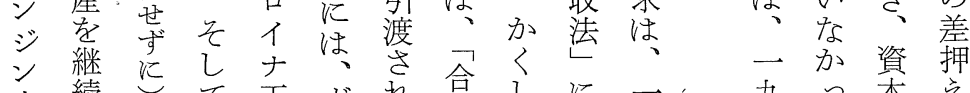

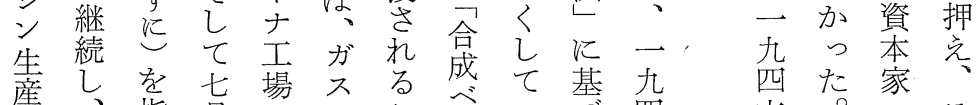

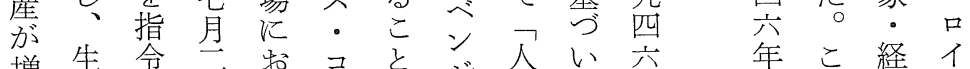

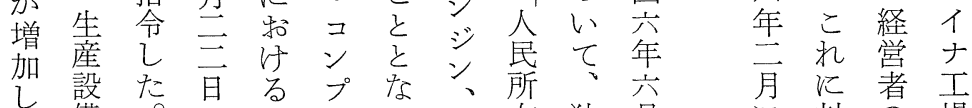

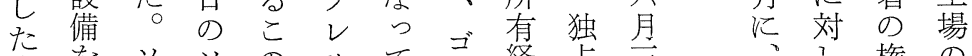

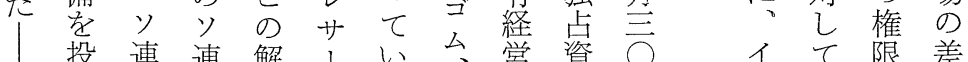
独だ指体

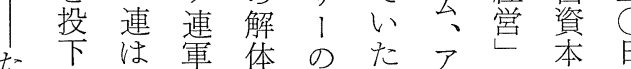
た下は、軍体 の た だロ官部体口等成没ザ 年拡イ部分唯イさ立收ク 末大士の的物大劣し㤎七 にた 場 令 で な

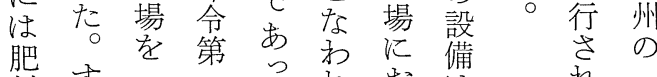

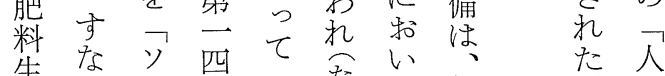

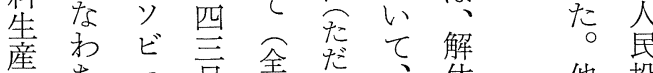

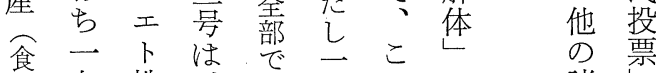
料九株食ば 一の 
一画 $厶$

見而良杂杂体四定注

期主四年江七権

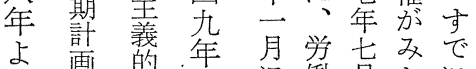

画的年觉堂働有で

四に敏 $\overrightarrow{0}$ 牲飞交

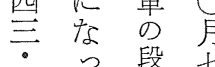

口段十不性y礼四

$\overrightarrow{\%} \tau$ 階旨莫連た六

增心㤎湯のと一六

乹た社、゙でアド杂月

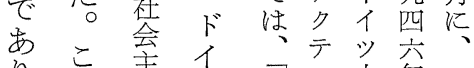

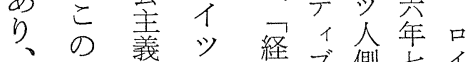

肥当的民紧軍側七イ

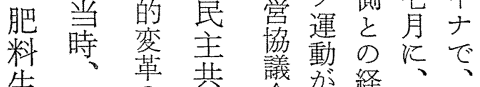

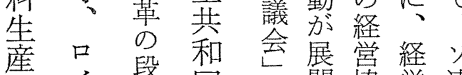

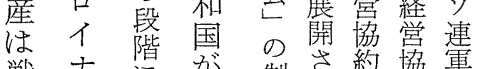

戦ナ湝㤎制さ約協軍

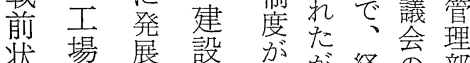

状場展設唯㕸経会部

態の生てさ解、営選々

老生てれ消㖣举々゙

回産口乞れイ議がイ

復は卆荟打ッ

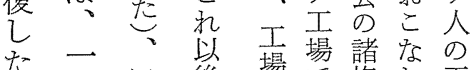

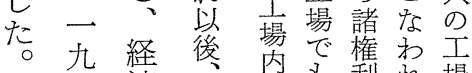

乙四済、内可利杂場

の旮計東学堌がた指

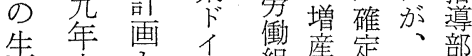

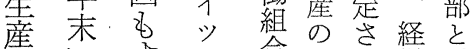

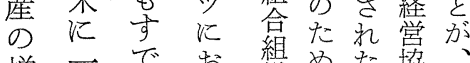

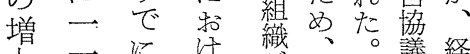

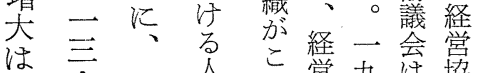

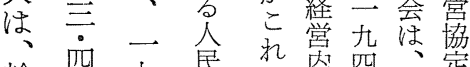

輸四九氐热四、定

掣\%四民代競分共を

岁遂杂主等争年同を

增行九街わが決导

大予吾鞤た势定定び

乙定○命な㳊そ

な年年和济の

上卡の机公中

て靣三反格東いで

現当离了

わで年シ 九市一共

枳穴計ズ四全九決

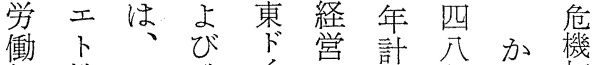
組株 フ戦、賠画年く打 合式 で会エ・究角をにてた

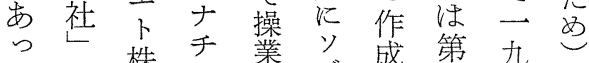
たに株の蒌ビ成筧見に す転会没杂学た峏重 連化社收た沙場年点

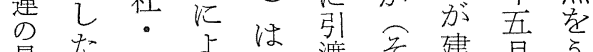

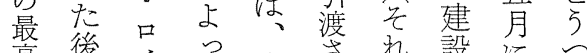
高後イっ東起投設つ

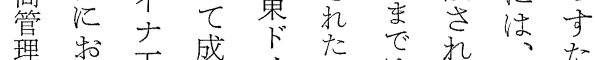

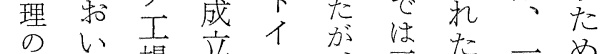

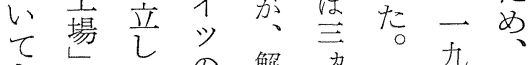

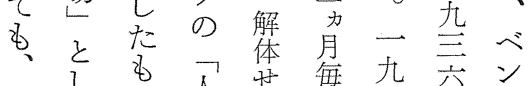

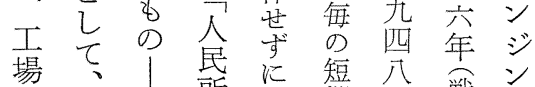

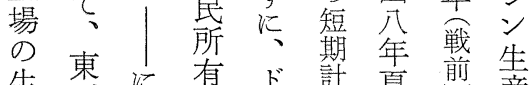

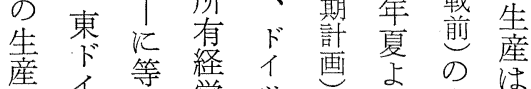
学真営商、引、生縮 繁の学 $\widehat{\mathrm{V}}$ 法こ一産小 㳊経帒 $\mathrm{E}$ 基国般六亲 推済経基良に、市た

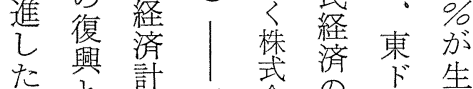
た爱計、式佩画生 の計画了会計イ産 は画のシ仼画ッさ ドの 音態化は、 1中組台交和計四

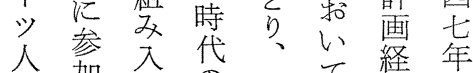

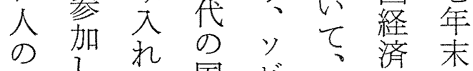

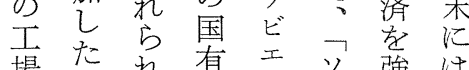
場年れ有エソ強は 指口た公有所ビ华第 嘎只か経有去し、至 部ナ㔔営経株下場 経工営武半唯 営場口独主会期建 協がイ占资社の設 議 フ 


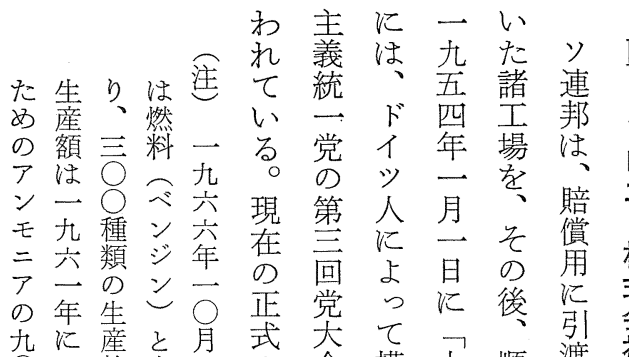

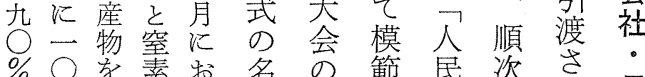

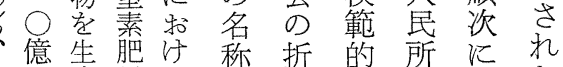
発急産料方称折的所飞热

動ルし従は等経ド㸴

機ク、で業

燃でそあ員

料、のるは

毛。約

厹杂尔品言 \%杂のナ人 㤎六恃撒二

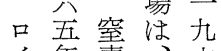

イ年素、六

ナの生ド-

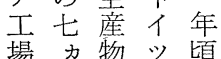

照年物民学䔛

生計肥街

産画料㳟言 石燃国人

て油料飞穴

掠华势工

学溶楊昜

新場片㝵面

た筷簀

な第エのは

石咅, 华半

油工学方

华場心檄年

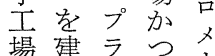

壮設最

文荋卡

ドたィの

民䇪号業云

主秀热場生

共料る留産

和の。㐫物

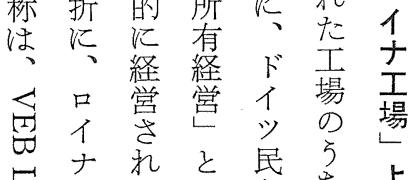

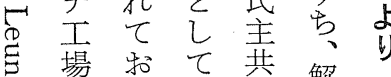

少り揫和解

离ヴこ登国哭

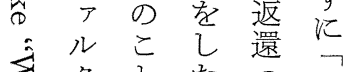

多文た た 無 ゾ

导!は償 ビ

只古遮卜

莺ブ旮し、株

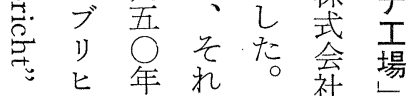

で卜七要社

あட月でイと

ると にナし

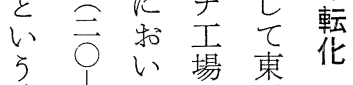

称三て注卡

号西名一个

与旦口九内

爷に五で

ら特ナ三生

れけ工年産

たる場末を

こドはに継

とイ、返続

にツ実還さ

も社質させ

表会的和て
の単営る輸

進江以突賠出

行只卡態償は

環寺い一拈一热

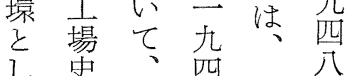

て店方突杂年

の汗年四川

みかわ分賠

政理は禁年党

治解、、

的岂敗无㐬㐬

済る後四\%务

的多分公方

正で菓年らら

乙

くなッ益四四

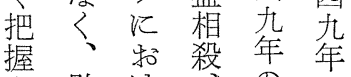

さ敗け、の

机戦る一一販

了後口无 \% 売

るのイ四に,

の東 ナ九減九

で市隼年少四

るツの黒た\%

に変学こ增

㳊・利の加

る発益占し

展とうた

反学恏登逆

了察乙展江

ジした の

ズた

- こ注用

民の 引

主過品渡

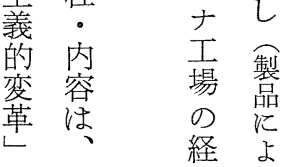




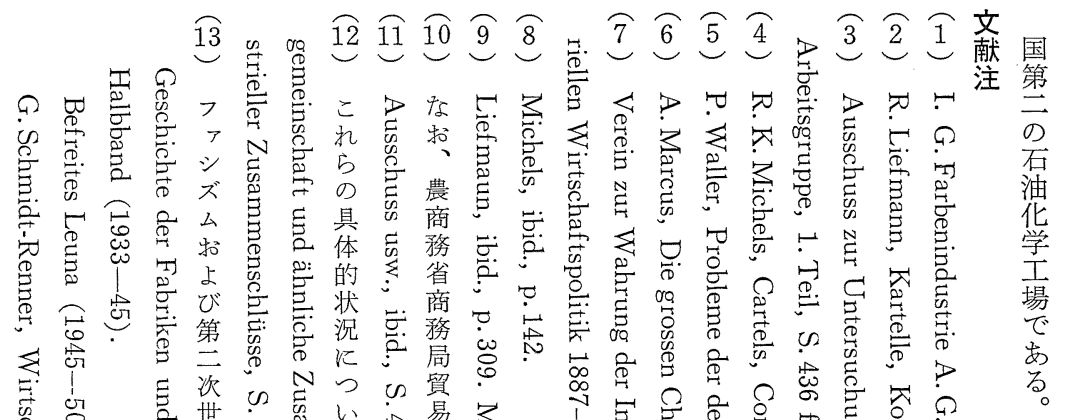

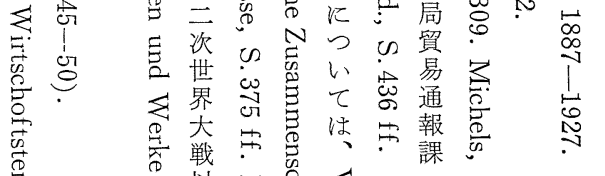

\section{g}

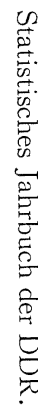

$\stackrel{8}{9}$

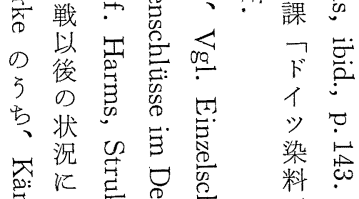

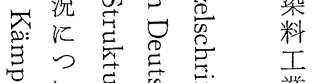

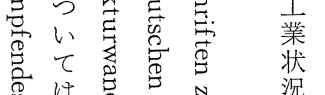

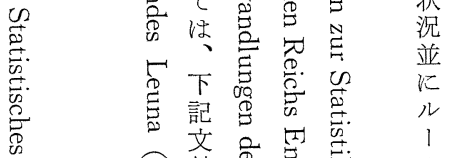

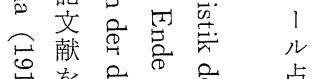

兽考

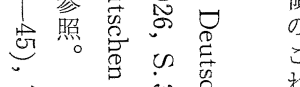

巴.

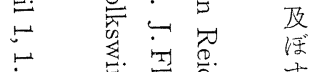

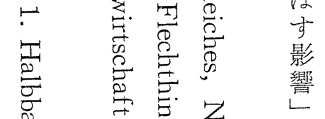

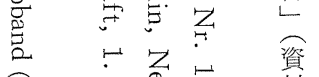

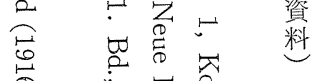

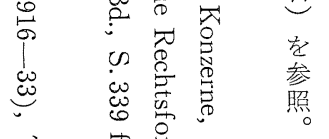

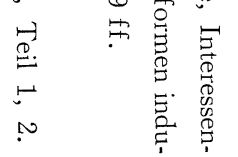

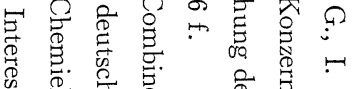

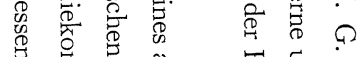

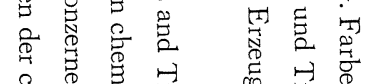

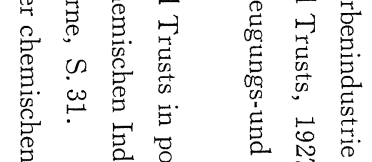

曋 志豆 员

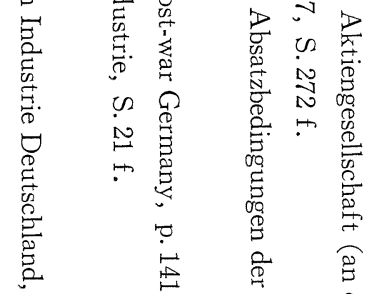

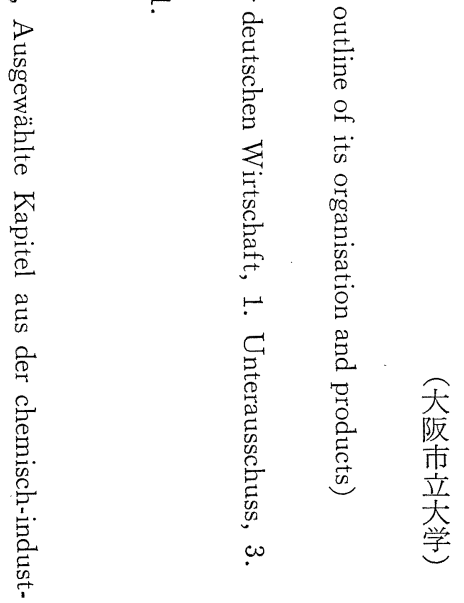




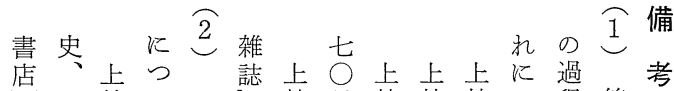

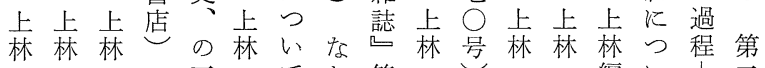

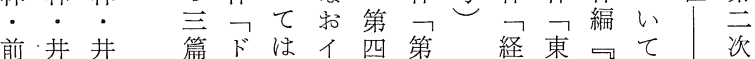
川上上をイ、1 学営ド社は東大 . . 共占ッ下ゲ巻次協イ会、ド戦 林義著く化記 1 一大議 ツ主こイ後 共我口む学の独・戦会に義こッの 著共工吉拙占二後さ扣のでに東

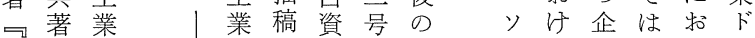
西古の集を本〕東ビる業省けイ ド現経共中参の卡尘経略るッ 个代済著史照歴个卡民営し社 企理 可し史ツ株所息会ド の業論世花て式有多の主イ 独形心界イい第拈会経タで義ッ 占態ミ産げた当け社営ヤ、企民 資論ミ業ゲだ次るる・のさ下業主 本省登昆き大成モ記の共

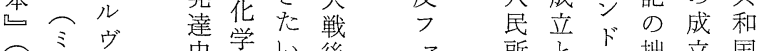

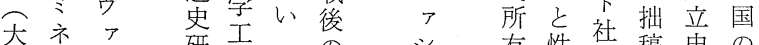
月ル書研業万の シ 有性过稿史の

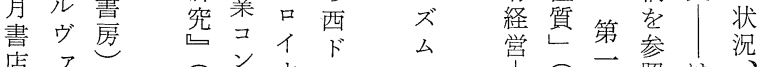

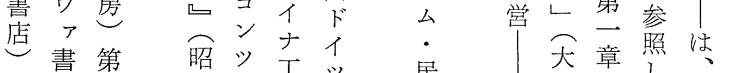

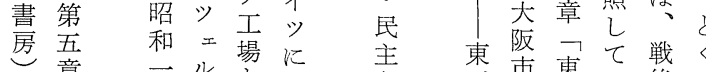

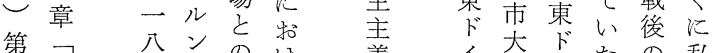
言独年史比る 義 の伊ド較イ 変に学ツききイ独 ド形藤イの1 革括部たた占 イ態畫ツただ゙ の の店华浊質

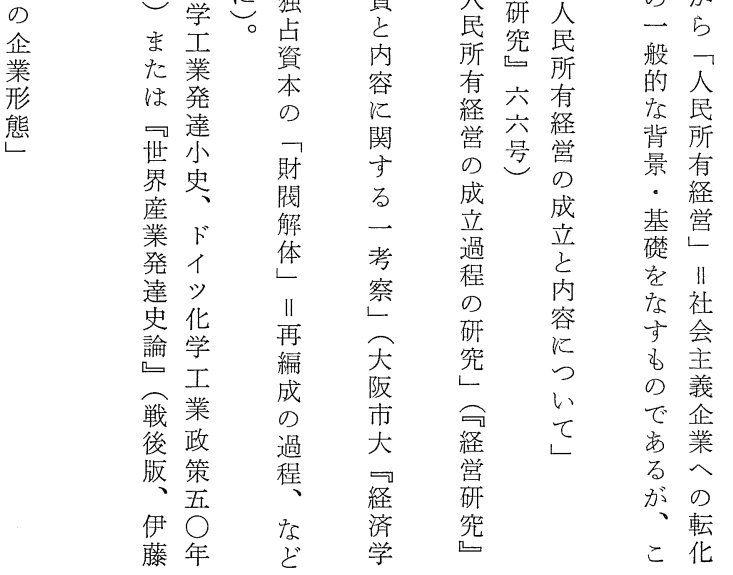




\title{
Zur Geschichte des Leuna-Werks des IG-Konzerns
}

\author{
by \\ Teijiro Kanbayashi \\ Osaka Municipal University
}

Die Geschichte des Leuna-Werks in Deutschland besteht aus zwei verschiedenen Abschnitte. Der erste Abschnitt von 1916 bis 1945 ist die Geschichte des Leuna-Werks als ein grosses Werk des I G-Monopolkapitals, und der zweite von 1945 bis heute ist die Geschichte als ein volkseigener Betrieb der DDR. Dieses Referat spricht hauptsächlich über den ersten Abschnitt.

Die Geschichte des Leuna-Werks als ein kapitalistisches Werk des I GKonzerns ist in zwei Bestandteile zu teilen, also, erstens die Geschichte der Entstehung und Entwicklung des I G-Monopolkapitals, zweitens die der Gründung und Entwicklung des Leuna - Werks selbst. Die Entstehung des I G-Trusts in 1925 war ein Erfolg des langen Entwicklungsprozesses der acht großen Chemiegesellschaften, die in 1904 zwei Interessengemeinschaften und dann in 1916 ein große Interessengemeinschaft bildeten. In 1925 wurden diese acht Gesellschaften in einem Trust, „I G Farbenindustrie AG“, fusioniert. Das Leuna-Werk selbst wurde in 1916 als ein Werk von „Die Badische Anilin-und Sodafabik" begründet, dann in 1920 als ihre Tochtergesellschaft, „Ammoniakwerke Merseburg GmbH, “ reorganisiert, und nach 1925 als das grösste Werk des I G-Monopolkapitals entwickelt. Aber die Niederlage des deutschen Imperiolismus in dem zweiten Weltkrieg war zugleich die Ende des Leuna-Werks als Werk des Monopolkapitals. Heute ist es „VEB LeunaWerke Walter Ulbricht" in der DDR. 